\title{
ON THE SUPPOSED JURY-DEPENDENCE OF EVIDENCE LAW
}

\author{
FREDERICK SCHAUER $^{\dagger}$
}

If there were no juries, would there be a law of evidence? And should there be? These questions are not about whether this or that rule of evidence owes its existence to the institution of the jury, and are thus not about whether particular evidence rules should be modified or eliminated when juries are not present. Nor are they about those many rules of evidence that are premised on such wildly mistaken folk wisdom about jury behavior that they are in desperate need of modification or elimination in light of what we now know from the social sciences about how people in general and juries in particular actually decide and deliberate. Rather, my question is whether the law of evidence, in the large, is so substantially a product of the institution of the jury itself that if juries did not exist, then vast swaths of evidence law would, and should, not exist as well.

This question is not merely of academic or historical interest. Numerous American trial judges, echoing what scholars since Jeremy Bentham have urged, ${ }^{1}$ essentially discard large chunks of the law of evidence when they sit without a jury. ${ }^{2}$ Time and again, especially in civil litigation and more than occasionally even in criminal cases, objections to the admissibility of evidence are met with the judicial re-

\footnotetext{
${ }^{\dagger}$ Frank Stanton Professor of the first Amendment, John F. Kennedy School of Government, Harvard University. This Article was written while I had the honor of serving as the Daniel R. Fischel and Sylvia M. Neil Distinguished Visiting Professor of Law at the University of Chicago. I am grateful for comments from Christopher Buccafusco, Laird Kirkpatrick, Richard McAdams, Dale Nance, Eric Posner, Chaim Saiman, Matthew Stephenson, and William Twining; from the members of the Drafts Reading Group at the Harvard Law School; and from the participants in the Legal Theory Workshop at the University of Pennsylvania Law School and the Works in Progress Seminar at the University of Chicago Law School.

${ }^{1}$ See infra Part I.

${ }^{2}$ See, e.g., Barry C. Feld, The Juvenile Court Meets the Principle of the Offense: Legislative Changes in Juvenile Waiver Statutes, 78 J. CRIM. L. \& CRIMINOLOGY 471, 477 (1987) (recounting departure from rules of evidence in juvenile proceedings); G. Michael Fenner, The Forced Use of Inadmissible Hearsay Evidence in Bankruptcy Court, 8 AM. BANkR. INST. L. REV. 453, 476 (2000) (describing disregard of evidence rules in bankruptcy trials); A. Leo Levin \& Harold K. Cohen, The Exclusionary Rules in Nonjury Criminal Cases, 119 U. PA. L. REv. 905, 908 (1971) (urging official recognition of widespread practice of ignoring rules of evidence in nonjury cases).
} 
sponse of, "I'll let it in and just give it the weight it deserves." $\mathrm{Be}-$ cause most of the rules of evidence are essentially exclusionary, and because judges (like the rest of us) do not want to screen themselves off from potentially useful information, many judges persistently treat the law of evidence as a counterproductive encumbrance to be jettisoned whenever possible. Indeed, there are frequent calls in the academic literature to make formally and legally permissible what all acknowledge to be the widespread informal practice. ${ }^{4}$

But are these trial judges and their academic forebears right? Is the law of evidence, which owes an appreciable part of its provenance to a concern about the cognitive or decision-making capacities of jurors, ${ }^{5}$ appropriately limited to the circumstances of its birth? When

\footnotetext{
3 "[J]udges presiding at non-jury trials often admit evidence indiscriminately, ruling on weight and relevance only after all the facts have been presented." Liana Gioia Per Ramfjord, Note, Reforming At-Will Employment Law: A Model Statute, 16 U. MiCH. J.L. REFORM 389, 426 (1983). For judicial acknowledgment and endorsement of the practice, see, for example, State v. Stout, 46 S.W.3d 689, 703 (Tenn. 2001) (adopting principle that trial judges should have "wider discretion than would normally be allowed under the [state's] Rules of Evidence" (quoting State v. Sims, 45 S.W.3d 1, 14 (Tenn. 2001))); Commonwealth v. Irwin, 639 A.2d 52, 54-55 (Pa. Super. Ct. 1994) (noting that trial judge is presumed to be able to disregard prejudicial evidence). In obvious frustration with what it saw as a widespread practice, the Seventh Circuit found it necessary to note that " $[\mathrm{t}]$ he Federal Rules of Evidence are statutes, and district judges may not disregard statutes no matter how inconvenient or cumbersome they believe the rules to be." In re Oil Spill by the Amoco Cadiz off the Coast of France on March 16, 1978, 954 F.2d 1279, 1305 (7th Cir. 1992); see also Mark I. Bernstein, Expert Testimony in Pennsylvania, 68 TEMP. L. REV. 699, 716 \& n.110 (1995) (noting tendency of judges to ignore rules of evidence regarding expert testimony in nonjury trials).

${ }^{4}$ See, e.g., James H. Chadbourn, Bentham and the Hearsay Rule-A Benthamic View of Rule 63(4)(c) of the Uniform Rules of Evidence, 75 HARV. L. REV. 932, 937 (1962) (presenting Bentham's argument for eliminating hearsay rule in both jury and nonjury cases); Kenneth Culp Davis, An Approach to Rules of Evidence for Nonjury Cases, 50 A.B.A. J. 723 (1964) (advocating distinct rules of evidence for nonjury trials); Peter L. Murray \& John C. Sheldon, Should the Rules of Evidence be Modified for Civil Non-Jury Trials?, 17 ME. B.J. 30 (2002) (urging formal approval of relaxed rules of evidence in civil nonjury cases); John Sheldon \& Peter Murray, Rethinking the Rules of Evidentiary Admissibility in Non-Jury Trials, 86 JUDICATURE 227, 231 (2003) ("[The role of t] he American law of evidentiary admissibility . . . in civil, non-jury proceedings is due for extinction.”).

${ }^{5}$ See Christopher B. Mueller \& LAIRD C. KirkPATRICK, EVIDENCE $§ 1.1$, at 2 (3d ed. 2003) (arguing that mistrust of juries is one of the primary reasons for evidence law); Henry M. Hart, Jr. \& John T. McNaughton, Evidence and Inference in the Law, in EVIDENCE AND INFERENCE 48, 56 (Daniel Lerner ed., 1959) (discussing rules of evidence "designed to exclude evidence to which the jury might give too much weight"); Edmund M. Morgan, The Jury and the Exclusionary Rules of Evidence, 4 U. CHI. L. REV. 247, 255 (1937) (noting that judicial discussions of hearsay rule indicate a distrust of jury's ability to handle such testimony). For the argument that the existence of the jury was a necessary but not sufficient cause of the development of a comprehensive law of evidence, and that the development of the corpus of evidence law was a product
} 
juries are removed from the picture, should much of the law of evidence be removed as well? Although rarely put in such stark terms, that conclusion reflects the conventional wisdom. ${ }^{6}$ Yet while this may be the conventional wisdom, my aim here is to ask whether the conventional wisdom is correct and to suggest some reasons for believing that it is not.

In asking this question about the foundations of evidence law, I take it as common ground that those rules of evidence serving extrinsic goals present almost wholly different issues from the ones I discuss here. Privileges, for example, do not purport to serve epistemic goals, ${ }^{7}$ and even those judges and commentators who question the need for juror-free evidence law typically have little problem with excluding properly privileged evidence-such as confidential conversations between spouses ${ }^{8}$ or between lawyer and client ${ }^{9}$ —even when juries are absent. And so too with various other rules-such as the inadmissibility of evidence of subsequent repairs and other remedial

of both the jury and the adversary system, see John H. Langbein, Historical Foundations of the Law of Evidence: A View from the Ryder Sources, 96 COLUM. L. REV. 1168, 1201-02 (1996). For the view that the exclusion of hearsay predates Anglo-American fears about jury mistakes, see Frank R. Herrmann, The Establishment of a Rule Against Hearsay in Romano-Canonical Procedure, 36 VA. J. INT'L L. 1 (1995). Cf. Crawford v. Washington, 541 U.S. 36, 53-54 (2004) (connecting history of hearsay exclusion with history of the right to confront opposing witnesses).

6 "[M] istrust of juries is the single overriding reason for the law of evidence." Christopher B. Mueller \& LAIRD C. KirKPATRICK, EVIDENCE UNDER THE RUles 1 (5th ed. 2004). The causal relationship between the institution of the jury and the entirety of the law of evidence is also one of the principal themes explored in MIRJAN R. DAMASKA, EVIDENCE LAW ADRIFT 26-57 (1997), although Damaska also attributes the rise of the rules of evidence to other adversarial and procedural attributes of the common law approach to litigation, $i d$. at 74-124. For an extensive account of this conventional "abolitionist" wisdom, see ALEX STEIN, FoundATIONS OF EvidENCE LAW 108-16 (2005).

${ }^{7}$ At least privileges do not typically serve the epistemic goals of the trial, although they may serve other epistemic goals, such as facilitating the production of knowledge in various out-of-court settings. For example, exclusion of otherwise relevant information communicated by a patient to a psychotherapist, see Jaffee v. Redmond, 518 U.S. 1, 15 (1996), may keep relevant information out of a trial, but may foster the provision by the patient to the psychotherapist of information relevant to treatment.

${ }^{8}$ See, e.g., United States v. Estes, 793 F.2d 465, 468 (2d Cir. 1986) (recognizing marital confidential communications privilege); People v. Daghita, 86 N.E.2d 172, 174 (N.Y. 1949) (same).

${ }_{9}$ See, e.g., United States v. Ramirez, 608 F.2d 1261, 1268 n.12 (9th Cir. 1979) (suggesting that privilege covers statements made both by lawyer and by client); United States v. Kovel, 296 F.2d 918, 922 (2d Cir. 1961) (holding that attorney-client privilege extends to communications with accountant assisting an attorney). 
measures to prove negligence or other culpable conduct, ${ }^{10}$ of liability insurance, ${ }^{11}$ and of plea bargain ${ }^{12}$ and settlement negotiations ${ }^{13}$ - that are designed to create the proper incentives for socially desirable outof-court conduct. Such rules are the exception, however, and most of the exclusionary rules are designed with the jury in mind and with the goal of increasing the accuracy and efficiency of fact finding under circumstances of jury decision making. In other words, they are (internally) epistemic and not extrinsic. Such rules comprise the bulk of evidence law and furnish its guiding inspiration, and it is such rules that are so often assumed to be largely jury dependent. ${ }^{14}$ My aim here is to question this assumption, not in terms of its historical accuracy, but in terms of the goals that the rules of evidence might now be properly thought to serve.

\section{THE SKEPTICAL TRADITION}

Interestingly, the entire law of evidence is a relatively modern creation. Although the exclusion of hearsay and rudimentary corroboration requirements are at least as old as the common law itself, the identification of evidence as a distinct legal realm and as a unified body of law postdates the law of, say, property, by at least several hundred years. There was no systematic attempt to compile the various bits and pieces of evidentiary rulings into a distinct topic until well into the eighteenth century. ${ }^{15}$ So when Jeremy Bentham launched his

${ }^{10}$ FED. R. EVID. 407.

${ }^{11}$ FED. R. EVID. 411.

${ }^{12}$ FED. R. EVID. 410.

${ }^{13}$ FED. R. EvID. 408.

${ }^{14}$ Even those who see the rules of evidence as a product of features of the common law adversarial system other than the presence of a jury, see DAMASKA, supra note 6 , at 75 (arguing that party control over evidence "affects the fundamentals of evidentiary thought"), appear to be largely convinced that a rule-based and exclusionary approach to evidence is fundamentally misguided, $i d$. at 142 (noting that decline of jury trials and weakening of the adversarial system may render evidentiary rules obsolete); see also Mirjan Damaska, Free Proof and Its Detractors, 43 AM. J. Comp. L. 343, 348-52 (1995) (comparing effects of exclusionary rules in the Anglo-American and continental legal systems).

${ }^{15}$ The seminal work is SiR JEFFrey GILbert, The LAW OF Evidence (London, Henry Lintot 1756) (1754). Even more comprehensive was THOMAS PEAKE, A COMPENDIUM OF THE LAW OF EVIDENCE (London, S. Rider 1801). See generally T.P. Gallanis, The Rise of Modern Evidence Law, 84 IOwA L. REV. 499 (1999); A.D.E. Lewis, The Background to Bentham on Evidence, 2 UTILITAS 195, 202 (1990) (tracing beginnings of evidence law to late seventeenth century and a "series of devices designed to widen the scope for the courts to interfere in the result arrived at by the jury"). 
attack on virtually the whole idea of evidence law in the early nineteenth century, ${ }^{16}$ it is fair to say that he was trying to nip what he saw as a dangerous weed in the bud, as opposed to attempting to dismantle a long-standing edifice. ${ }^{17}$

Bentham is of particular interest to us because he framed the issue in a way that leaves no doubt about what is at stake. For Bentham, the rules of evidence-almost all of them-were needless and often suboptimizing distractions. The ideal system, he proposed, was one of "free proof," an approach, to oversimplify only slightly, in which evidence was admitted if logically relevant-if the consideration of some piece of evidence made a proposition more or less likely than it would have been without that evidence-and was then given the weight that its intrinsic and particular probative value justified. ${ }^{18}$ Thus, courts would proceed just as ordinary people proceeded when using their common sense to make everyday factual determinations. ${ }^{19}$ In making ordinary nonjudicial factual determinations, people do not, insisted Bentham, make use of artificial rules of exclusion or need special rules of corroboration for entire classes of events. And thus there was no justification for the law to do otherwise. Free Proof, for Bentham and his followers, was simply ordinary epistemology applied to legal matters, ${ }^{20}$ and that is why Bentham favorably compared what he la-

${ }^{16}$ Jeremy Bentham, Rationale of Judicial Evidence (John S. Mill ed., Fred B. Rothman \& Co 1995) (1827). Especially noteworthy is Bentham's claim that "[a]lmost every rule that has ever been laid down on the subject of evidence" is "repugnant to the ends of justice." 1 BENTHAM, supra, at 4 . For extensive discussion, see William Twining, THEORIES OF EVIDENCE: BENTHAM AND WigmORE (1985); Lewis, supra note 15, at 203-16. For the view that Bentham's critique of the exclusionary rules of evidence may be somewhat narrower than is commonly supposed, see Dale A. Nance, The Best Evidence Principle, 73 IOWA L. REv. 227, 275 (1988).

${ }^{17}$ Thus, as late as 1794, Edmund Burke observed, at the trial of Warren Hastings, that the law of evidence was "comprised in so small a compass that a parrot ... might get them by rote in one half-hour and repeat them in five minutes." WILLIAM TWINING, RETHinking EVIDENCE: Exploratory Essays 37 (Cambridge Univ. Press 2d ed. 2006) (1990).

${ }^{18} I d$. at 209 (stating that Bentham's notion of Free Proof allowed for no restrictions other than the "general principles of practical reason").

19 "A large class of 'exclusionary' rules bars certain types of evidence from reaching the trier of fact, though these same types of evidence would cheerfully and blithely be regarded as probative in everyday life." ALVIN I. GOLDMAN, KNOWLEDGE IN A SOCIAL WORLD 291 (1999).

${ }^{20}$ See Susan Haack, Epistemology Legalized: Or, Truth, Justice, and the American Way, 49 AM. J. JURIS. 43, 56 (2004) ("[T] hat exclusionary rules are inherently at odds with the epistemological desideratum of completeness. . . . is the main theme of Bentham's treatise on evidence...."). 
beled the Natural System to its obvious (at least to him) inferior, the Technical System. ${ }^{21}$

Although Bentham's views did not carry the day in undiluted form, they have been profoundly influential, if only to put on the permanent defensive anyone who might dare to think that there ought to be rules of evidence-especially nondefeasible exclusionary rules, as opposed to general but highly defeasible principles (or standards, if you will) of applied epistemology. ${ }^{22}$ And in the face of this shift in the burden of proof (another one of the rules that Bentham would have eliminated), a tradition developed of explaining the rise and continuation of the rules of evidence as being substantially the byproduct of the institution of the jury. This was the signal contribution of James Bradley Thayer, who in 1898 in his A Preliminary Treatise on Evidence at the Common Law emphasized the essential narrowness of the exclusionary rules of evidence, urged that they be yet narrower still, and justified the ones that did and should remain as the consequence either of principles of substantive (and not procedural) law or in order to take account of the likely failings of juries. ${ }^{23}$ For Thayer, and for many who followed him, it was the jury that was at the heart of understanding the essentially peculiar and often counterproductive institution of the law of evidence.

Thayer's impact has turned out to be less through his Treatise and more through his teaching and his students, the most prominent of

${ }^{21}$ See TwinING, supra note 16, at 48-51 (summarizing characteristics of Natural and Technical systems). There is an important parallel here between Bentham's view about the worth (or not) of rules of evidence and his view about the limited value of rules in general. See Gerald J. Postema, Bentham And the Common Law Tradition 224-25 (1986). Just as Bentham thought that rules were important for the public but less so, to put it mildly, for judges and lawmakers, so too did he think much the same thing about the rules of evidence. But for a skeptical view of Bentham's influence on subsequent evidence law, see C.J.W. ALLEN, THE LAW OF EVIDENCE IN VICTORIAN ENGLAND 7 (1997). And for an account of Bentham's view of rules that diverges in part from Postema's, see John Dinwiddy, Bentham, in Bentham: Selected Writings of JOHN DINWIDDY (William Twining ed., 2004).

${ }^{22}$ See Laird C. Kirkpatrick, Scholarly and Institutional Challenges to the Law of Evidence: From Bentham to the ADR Movement, 25 LOY. L.A. L. REV. 837, 847, 850 (1992) (describing Bentham's preference for evidentiary principles rather than rules). It is important to note that the issue is not whether the rules of evidence should be codified in something like the Federal Rules of Evidence or the California Evidence Code. Rather, it is whether the admission or exclusion of evidence should be governed by rules at all, regardless of whether those rules are common law rules or parts of comprehensive evidence codes.

${ }^{23}$ JAMES BRAdLEy Thayer, A PRELIMINARY TREATISE ON EVIDENCE AT THE COMMON LAW 508-38 (Boston, Little, Brown \& Co. 1898). 
whom was John Henry Wigmore. Wigmore is known primarily for his monumental and largely descriptive systematization of the law of evidence, ${ }^{24}$ but he also had a prescriptive side. ${ }^{25}$ And when dealing not with what the law of evidence was, but instead about what it ought to be, Wigmore urged the development of a science of proof that was logically antecedent to the rules of evidence, and that would remain important even were the rules of admissibility—which he viewed as artificial-to be abolished. ${ }^{26}$ Certain fundamental principles underlying these artificial rules, insisted Wigmore, were highly important, but their importance was attributable almost entirely to the existence of the jury. ${ }^{27}$ Juries could hardly be trusted, Wigmore and many others believed, to apply the more scientific principles of proof directly to particular issues, and thus needed rules of evidence to steer them in the right direction. ${ }^{28}$ Such steering would not be necessary for legally

${ }^{24}$ John Henry Wigmore, Evidence In Trials at Common LAW (Peter Tillers ed., 1983).

${ }^{25}$ See TwINING, supra note 16, at 117 (describing Wigmore's opposition to rigid rules; instead proposing that evidence rules should provide mere guidance).

${ }^{26} 1$ WigmORE, supra note $24, \S 8$ (c), at 630 ("A complete abolition of the rules in the future is at least arguable, not merely in theory but in realizable fact. ... [I]n the United States ... justice can be done without the orthodox rules of evidence.").

${ }^{27}$ Id. $\$ 8(\mathrm{c})$, at 632 .

${ }^{28} I d$. at 632-33 (discussing "weaknesses" of jurors). As I will develop at greater length in Part IV, there is an interesting parallel here to the literature on act- and ruleutilitarianism. Infra Part IV; see, e.g., J.J.C. Smart, Extreme and Restricted Utilitarianism, in CONTEMPORARY UTILITARIANISM 99 (Michael D. Bayles ed., 1968) (discussing opposing views in utilitarianism as to whether actors should follow rules or make moral judgments on a case-by-case basis). Most obviously to the point is R.M. Hare's infelicitously labeled distinction in Moral Thinking: Its Levels, Method and Point between "archangels" and "proles." R.M. HARE, MORAL Thinking: Its LeVels, Methods, AND POINT 44-45 (1981). For Hare, direct application of the principles of utility was beyond the capacities of the proles even if not for the (more ideal than real) archangels, and so although the more-or-less mythical archangels might be entrusted with this responsibility, the more-or-less mythical proles should be given more mechanical rules which, when applied by them, would produce more utility than would be produced were the proles entrusted with direct application of utilitarian principles. See id. at 46-47. This idea, similar to John Stuart Mill's argument in Utilitarianism for (falsely) teaching the importance of justice to ordinary people as a way of getting them to produce the maximum amount of utility, John Stuart Mill, Utilitarianism, in THE BASIC WRITINGS OF JOHn StUART Mill 233, 277-301 (Dale E. Miller ed., 2002), and similar to a number of arguments presented by Henry Sidgwick, HenRY SidGWICK, THE METHODS OF ETHICS 440-50 (7th ed. 1981) (discussing the utilitarian basis for rules of justice), is plainly relevant to the debates about juries and the rules of evidence. In many of these debates, judges-especially in the eyes of judges-are the archangels, and jurors are the proles. So although jurors are thought not to be trusted to apply scientific and philosophical principles of proof directly-hence the exclusionary rules of evidence- 
astute judges, however, ${ }^{29}$ and thus the view developed that the law of evidence, to the extent it was necessary at all, was necessary largely because of the cognitive and epistemic failings of juries.

\section{EXIT THE JuRY}

Were all, or even much, litigation to take place before a jury, questioning the jury-dependence of the bulk of evidence law might be of little more than academic or historical interest. In fact, however, jury trials are very much the exception rather than the rule, and this becomes more and more true every day. The positions of Bentham, Thayer, Wigmore, and others ${ }^{30}$ are thus increasingly important precisely because the jury has become an endangered institution worldwide. Even in the United States, the number of criminal and civil jury trials has declined substantially in recent years. ${ }^{31}$ And in every common law country outside the United States, the civil jury has for all practical purposes disappeared, ${ }^{32}$ with libel cases typically being virtu-

there would, under this view, be no reason not to allow judges to do so when the jury is removed from the picture.

${ }^{29}$ And, a fortiori, in those legal systems not employing juries as finders of fact.

${ }^{30}$ See supra note 4; see also Charles T. McCormick, Tomorrow's Law of Evidence, 24 A.B.A.J. 507, 580-81 (1938) (questioning the value of exclusionary rules of evidence as the institution of trial by jury diminishes in significance).

${ }^{31}$ See Marc Galanter, The Vanishing Trial: An Examination of Trials and Related Matters in Federal and State Courts, 1 J. EMPIRICAL LEGAL STUD. 459, 462 tbl.1, 512 tbl.7 (2001) (showing a decreasing rate of jury trials as a percentage of total trials over time); PAtrick Walker \& Pragati Patrick, Administrative OfFice of the United STATES COURTS, TrendS IN Firearms CASES From FisCAL YEAR 1989 Through 1998, AND THE WORKLOAD IMPLICATIONS FOR THE U.S. District COURTS (2000), www.uscourts.gov/firearms/firearms00.html (indicating that between 1989 and 1998, there was a thirty-eight percent decline in jury trials for all criminal offenses). What the existing research shows is that the decline in jury trials is not attributable to a decline in the number of trials, but that it is at least in part attributable to a decline in the proportion of jury trials within the domain of trials.

${ }^{32}$ See, e.g., John Henry Merryman et al., The Civil Law Tradition: Europe, LATIN AMERICA, AND EAST ASIA 1014 (1994) (stating that in common law countries other than the United States, "the civil jury has been abolished"); RICHARD A. POSNER, The Federal COURTS: Challenge AND REFORM 193 n.1 (1996) ("[T] he abolition of the jury in civil cases [is] a course that the rest of the civilized world took long ago ...."); KONRAD ZWEIGERT \& HEIN KOTZ, AN INTRODUCTION TO COMPARATIVE LAW 280 (Tony Weir trans., 2d ed. 1987) ("Jury trials admittedly occur only in criminal cases in England today...."); Neil Vidmar, A Historical and Comparative Perspective on the Common Law Jury, in WORLD JuRY Systems 1, 3 (Neil Vidmar ed. 2000) (“[W]ith the exception of the United States and parts of Canada, the jury has been largely abandoned for civil cases...."). It is an interesting question how much of the United States's outlier status is attributable to the Seventh Amendment and its state constitu- 
ally the sole exception. Indeed, in some common law countries even the criminal jury is in rapid decline. South Africa eliminated criminal as well as civil juries almost forty years ago, and it is noteworthy and surprising that there has been almost no move to reinstate even the criminal jury in post-apartheid South Africa. ${ }^{33}$ Even in those common law countries that do retain the criminal jury, such as Great Britain, Ireland, Canada, New Zealand, and Australia, the actual number of trials in which a jury sits is rapidly declining, with more and more of the business of criminal adjudication being allocated to magistrates' courts in which there is generally no jury at all. ${ }^{34}$

When we look at the countries outside of the United States in which the jury is in decline, we see a commensurate decline-just as Bentham, Thayer, and Wigmore would have predicted-in the law of evidence as well. In 1972 Rupert Cross, at the time the leading English authority on the law of evidence, ${ }^{35}$ announced in a debate about the Criminal Law Revision Committee that he was working for the day when his own subject would be abolished. ${ }^{36}$ In magistrates' courts in England, Australia, and New Zealand it is the brave lawyer indeed who makes an evidentiary objection. ${ }^{37}$ The standard South African treatise on the law of evidence ${ }^{38}$ is a far sparser work than its American counterparts, and even the rules that exist in South Africa are ever more

tional counterparts and how much to the efforts of interest groups like the American Trial Lawyers Association.

${ }^{33}$ See Christopher Roederer, The Transformation of South African Private Law After Ten Years of Democracy: The Role of Torts (Delict) in the Consolidation of Democracy, 37 COLUM. HUM. RTS. L. REV. 447, 456 n.34 (2006) (noting abolition of criminal juries in South Africa); Tracy Gilstrap Weiss, Comment, The Great Democratizing Principle: The Effect on South Africa of Planning a Democracy Without a Jury System, 11 TEMP. INT'L \& COMP. L.J. 107, 122 (1997) (discussing lack of support in the South African legal community for reinstatement of juries).

${ }^{34}$ See, e.g., Neil Cameron et al., The New Zealand Jury, LAW \& CONTEMP. Probs., Spring 1999, at 103, 106 (1999) (documenting shift toward magistrate and district court trials in New Zealand); Kimberly Ann Page, The Sale of English Justice, 29 DENV. J. INT'L L. \& POL'Y 1, 1-6 (2000) (lamenting increased use in the United Kingdom of nonjury courts for criminal trials).

35 See Rupert Cross, Evidence (5th ed. 1979); Rupert Cross, An AtTempt to UPDATE THE LAW OF EVIDENCE (1973); RUPERT Cross \& NANCY WILKINS, AN OUTLINE OF THE LAW OF EVIDENCE (3d ed. 1971); J.D. HEYDON, CROSS ON EVIDENCE (6th Austl. ed. 2000); COLIN TAPPER, CROSS ON EVIDENCE (7th ed. 1990).

${ }^{36}$ The episode is described in TwINING, supra note 17, at 1 . Cross's more nuanced and well-developed position is set out in Rupert Cross, The Evidence Report: Sense or Nonsense-A Very Wicked Animal Defends the 11th Report of the Criminal Law Revision Committee, 1973 CRIM. L. REV. 329.

${ }^{37}$ TWINING, supra note 17 , at 212.

38 L.H. Hoffman, The SOUth AFrican Law OF Evidence (2d ed., 1970). 
rarely enforced in courts or taken seriously by judges. ${ }^{39}$ And the same trend can be found in Canada, Ireland, Australia, New Zealand, and much of the rest of the non-American common law world. ${ }^{40}$ The law of evidence does still exist in all of these increasingly, or entirely, juryfree countries, but the widespread belief in such jurisdictions is that it exists substantially as a path-dependent relic of earlier days; something to be taken lightly at all times and ignored whenever possible. ${ }^{41}$

This view of the jury-dependence of evidence law is compatible with the state of affairs in the typically jury-free civil law world as well. In civil law countries, the jury is largely an alien institution, so it is not too much of an overstatement to say that the law of evidence simply never developed at all. ${ }^{42}$ There are, in civil law jurisdictions, various bits and pieces of evidentiary rules that resemble some of the common law rules of evidence, but the civil law neither has a systematic law of evidence nor, not surprisingly, does it have its Thayers or its Wigmores or its Morgans or its Crosses to explicate it. ${ }^{43}$ As a matter of historical and comparative fact, therefore, it is hard to deny that the existence of the jury has been a substantial (even if not exclusive) cause of the de-

${ }^{39}$ I am grateful to Sir Richard Goldstone for discussion on this point.

${ }^{40}$ See, e.g., Khan v. The Queen, [1990] 2 S.C.R. 531, 548 (Can.) (recognizing an exception to the hearsay rule allowing evidence regarding a child's statements regarding a crime committed against the child, subject to consideration of "necessity and reliability"); Morris v. Cameron, [2006] 240 N.S.R.2d 123, para. 25 (Can.) (allowing introduction of hearsay evidence that "does not fall under an existing hearsay exception" based on consideration of its "necesssity and reliability"); David M. Tanovich, Starr Gazing: Looking into the Future of Hearsay in Canada, 28 QUEEN's L.J. 371 (2003) (analyzing future impact of the relaxed, "necessity and reliability" approach to hearsay evidence adopted in Canadian courts).

${ }^{41}$ See Laird C. Kirkpatrick, Evidence Law in the Next Millennium, 49 Hastings L.J. 363, 365 (1998) ("[A]fter England abolished the right to a jury trial in most civil cases, it then significantly expanded the admissibility of hearsay.”).

${ }^{42}$ See Kenneth Culp Davis, An Approach to the Rules of Evidence for Nonjury Cases, 50 A.B.A. J. 723, 726 (1964) (urging the Anglo-American legal world to follow the European civil law tradition and largely eliminate those rules that eliminate the use of "evidence that has probative force"); see also Damaska, supra note 14, at 343-48; Karl H. Kunert, Some Observations on the Origins and Structure of Evidence Under the Common Law System and the Civil Law System of "Free Proof" in the German Code of Civil Procedure, 16 Buff. L. REV. 122, 141-43 (1966); John H. Langbein, The German Advantage in Civil Procedure, 52 U. CHI. L. REV. 823, 829 (1985) (noting the lack of a counterpart to AngloAmerican evidence law in Germany); M-L. Rassat, Forensic Expertise and the Law of Evidence in France, in FORENSIC EXPERTISE AND THE LAW OF EVIDENCE 53, $53-57$ ( J.F. Nijboer et al. eds., 1993).

${ }^{43}$ See Mirjan Damaska, Evidentiary Barriers to Conviction and Two Models of Criminal Procedure: A Comparative Study, 121 U. PA. L. REV. 506, 509 (1973) (noting, in regard to rules of evidence, that "there is so much highly complex law on the common law side and so little law on the civil law side"). 
velopment (and to a significant extent the continuation) of anything resembling a comprehensive law of evidence. ${ }^{44}$

\section{The Ascendency of Free Proof}

Against this historical and comparative background the views of so many contemporary American trial judges ${ }^{45}$ are not difficult to explain. We know that the law of evidence, as a historical matter, arose to a significant extent because of the institution of the jury. We know that there have been influential skeptics about the entire body of evidence law for almost two centuries, and that defenders of evidence law against these skeptical attacks have relied largely on the alleged cognitive, rational, and deliberative failings of juries. We know that legal systems that have never had juries have never developed a comprehensive law of evidence. And we know that legal systems that have seen the jury decline in importance have seen a commensurate decline in importance in the law of evidence. So, against this background, it is surely no surprise to discover that even in the United States, where the decline in the use of the jury has been the smallest, the immediate absence of a jury is taken by many trial judges as sufficient cause to treat the law of evidence as somewhere between only mildly suggestive and largely irrelevant. Nor is it a surprise to discover that in the United States, as elsewhere, there is an active call to discard the (intrinsic) formal rules of evidence in favor of something resembling a Free Proof system when a jury is not part of the picture. ${ }^{46}$

This attitude is most apparent with respect to hearsay. Putting aside criminal cases, where the exclusion of hearsay serves diverse purposes enshrined in the Sixth Amendment by the Confrontation

\footnotetext{
${ }^{44}$ Even those who see the existence of the jury as only one of the multiple causes of the development of the law of evidence, see DAMASKA, supra note 6, at 2-4 (suggesting that the adversary system may be part of the root of evidence law); Langbein, supra note 5, at 1197 (tracing the source of evidentiary law to "the rise of adversary criminal procedure"), do not deny that the existence of the jury has been a significant contributory factor. Nor do they claim that the law of evidence in common law countries would be what it has become without the historical presence of the institution of the jury trial.

${ }_{45}$ And not-so-contemporary ones as well. See Learned Hand, Address to the Association of the Bar of the City of New York: The Deficiencies of Trials to Reach the Heart of the Matter (November 17, 1921), in LECTURES ON LEGAL TOPICS: 1921-22, at 89, 98-99 (1926) ("Much of the delay and bickering which does more than deface a court room would be avoided by a recognition that the rules of evidence are practical and discretionary.").

${ }^{46}$ See supra note 4.
} 
Clause ${ }^{47}$ the traditional operation of the hearsay rule ordinarily produces the exclusion of logically relevant and, thus, otherwise admissible and useful evidence. ${ }^{48}$ We can have greater confidence in the truth of what Jane told Sam, as recounted at trial by Sam in the absence of Jane, when we have Sam's testimony than when we do not. It is true, to be sure, that the opportunity to cross-examine Jane would increase the ability to test the truth of Jane's statement, ${ }^{49}$ but the value of Jane's statement as recounted by Sam even without the opportunity to cross-examine Jane is rarely zero. To put it in Bayesian terms, we approach the question of the likely truth of some proposition with a prior probability of the truth of that proposition, and if we are then told by Sam that Jane affirmed that proposition, we would typically believe that the probability of the truth of that statement has risen by virtue of even our second-hand knowledge of Jane's endorsement of it, especially if there is reason to believe that Jane had actual knowledge, even if there is no opportunity to test Jane's knowledge or the truth of her assertion by cross-examination, by observing her demeanor, or by putting her under oath. Yet although Jane's out-of-court statement thus ordinarily has between some and a considerable degree of probative value, such a prototypical hearsay statement would usually (and under the existing rules properly) be excluded, ${ }^{50}$ not because it is not probative, but despite the fact that it is probative, and very often highly so.

There are, of course, numerous exceptions to the categorical exclusion of hearsay. The Federal Rules of Evidence list at least thirty, ${ }^{51}$

${ }^{47}$ See Davis v. Washington, 126 S. Ct. 2266 (2006); Crawford v. Washington, 541 U.S. 36 (2004)

48 “[T] he exclusion of hearsay... strikes at the root of the jury's function by usurping its power to process quite ordinary evidence, the type of information routinely encountered by jurors in their everyday lives." Note, The Theoretical Foundation of the Hearsay Rules, 93 HARV. L. REV. 1786, 1805 (1980).

${ }^{49}$ See United States v. Evans, 216 F.3d 80, 85 (D.C. Cir. 2000) ("Cross-examination may be the 'greatest legal engine ever invented for the discovery of truth' ...." (quoting California v. Green, 399 U.S. 149, 158 (1970))); Leake v. Hagert, 175 N.W.2d 675, 683 (N.D. 1970) (noting that cross-examination reveals "the grounds of [a witness's] assertion and his qualification to make it”); Roger Park, A Subject Matter Approach to Hearsay Reform, 86 MiCH. L. REV. 51, 57 (1987) ("[One] justification for excluding hearsay depends upon the belief that a witness describing an out-of-court statement is likely to be less reliable than a witness describing nonverbal events, or at least that cross-examination will be less effective on a witness to a statement.").

${ }^{50}$ See FED. R. EVID. 801 (c), 802.

${ }^{51}$ The structure of Rules 801, 803, and 804 of the Federal Rules of Evidence makes an exact count difficult. Some of what were previously exceptions (party admissions, most prominently) are now defined as non-hearsay in Rule 801(d), see FED. R. 
and then include the catchall Rule 807 just in case old ones were forgotten or new ones emerge. Yet even though there are many exceptions, it would be a mistake to underestimate the force of the basic rule, which especially but by no means only in criminal trials, plainly excludes a substantial amount of otherwise relevant evidence. And because hearsay evidence is so often obviously logically relevant, we can see the initial appeal of its formal elimination when a jury is not part of the picture, and we can see as well why it is ubiquitous that judges, magistrates, arbitrators, masters, and diverse other adjudicators, when sitting without a jury, will typically but more informally allow hearsay evidence to be offered, announcing that such evidence will be given exactly the weight its intrinsic probative value deserves, presumably discounted for the epistemic losses coming from a nonfirst-hand account, from the want of an oath, from the lack of an opportunity to cross-examine the declarant, and from the absence of the ability of the trier of fact to observe the declarant's demeanor. But implicit in current practice in nonjury settings in the United States and elsewhere is the fact that such a discount in epistemic value is never total, which is simply another way of saying that the evidence is admitted and given the weight that it is thought, in the final analysis and in the particular case, to deserve.

A similar conclusion prevails with respect to the so-called best evidence rule, more properly called the original documents rule. ${ }^{52}$ As with hearsay, the evidence excluded under strict application of the original documents rule is only infrequently irrelevant in the logical sense. When presented with a copy of some document, even an unclear copy under somewhat suspicious circumstances, we rarely in ordinary life discount its epistemic value entirely. Rather, we treat the possibility of miscopying or worse as a reason to discount the reliability of the evidence. This discounting rarely produces a probative value of zero, however, despite the fact that this is precisely what a strict ap-

EVID. 801(d) (identifying statements that are not hearsay), and many of the remaining exceptions set forth in Rules 803 and 804 have numerous parts, see FED. R. EVID. 803 (providing extensive hearsay rule exceptions even when declarant is available as a witness); FED. R. EVID. 804 (listing hearsay exceptions when declarant is unavailable as a witness).

${ }^{52}$ See FED. R. EVID. 1001-1008. The common law rule is well stated and applied in Sirico v. Cotto, 324 N.Y.S.2d 483, 486 (Civ. Ct. 1971). See also Meyers v. United States, 171 F.2d 800, 813 (D.C. Cir. 1948) (stating that the best evidence rule is more than a "legal cliché" and must be enforced). 
plication of the original documents rule does in actual practice. ${ }^{53}$ But because the original documents rule tends towards the exclusion of otherwise useful evidence, it, like the hearsay rule, sees itself applied increasingly narrowly, and sees itself the subject of persistent calls for its elimination as well. ${ }^{54}$

Much the same can be said about the various forms of character and propensity evidence, ${ }^{55}$ about many of the exclusions of expert testimony $^{56}$ (even after the arguably limiting approach of Daubert $v$. Merrill-Dow Pharmaceuticals, Inc. ${ }^{57}$ and Kumho Tire Co. v. Carmichael ${ }^{58}$ ), about some of the exclusions of opinion evidence, ${ }^{59}$ about a number

\footnotetext{
${ }^{53}$ I do not mean to ignore the extent to which the original documents rule-like the hearsay rule, the authentication requirements, and much else-has been weakened in recent years, with much of this weakening now enshrined in the Federal Rules of Evidence. See, e.g., Herzig v. Swift \& Co., 146 F.2d 444, 445 (2d Cir. 1945) (Frank, J.) ("Perhaps the most to be said for the 'best evidence rule' is that it may serve on occasion as a good mnemonic device."); Kenneth S. Broun, Authentication and Contents of Writings, 1969 LAW \& SOC. ORDER 611, 612-24 (assessing the effect of codification under the Federal Rules of Evidence). But because much of the impetus for this weakening is exactly what I challenge here, I will continue to focus on what remains, rather than on what has been relaxed or eliminated.

54 See Herzig, 146 F.2d at 445 (questioning the value of the original documents rule); see also United States v. Winkle, 587 F.2d 705, 712 (5th Cir. 1979) (concluding that a plain violation of the best evidence rule was not grounds for reversal); Edward M. Cleary \& John W. Strong, The Best Evidence Rule: An Evaluation in Context, 51 IowA L. REV. 825, 847-48 (1966) (concluding that the best evidence rule will diminish as the scope of discovery expands).

${ }^{55}$ See FED. R. EvID. 404-405; see also David P. Leonard, The Use of Character to Prove Conduct: Rationality and Catharsis in the Law of Evidence, 58 U. COLO. L. REV. 1, 56-57 (1987) (urging modification of existing rules so as to allow use of character evidence in civil cases); MUELLER \& KIRKPATRICK, supra note 5, § 4.15, at 193 (concluding that Rule 404(b) "adopts an inclusionary rather than exclusionary approach" to much evidence of past acts and wrongs); Mirjan R. Damaska, Propensity Evidence in Continental Legal Systems, 70 CHI.-KeNT L. REV. 55, 55 (1994) (suggesting that rules against character evidence are problematic).

${ }^{56}$ See Tuf Racing Prods., Inc. v. Am. Suzuki Motor Corp., 223 F.3d 585, 591 (7th Cir. 2000) (holding that formal credentials are not necessary to qualify as expert witness); In re Paoli R.R. Yard PCB Litig., 35 F.3d 717, 741 (3d Cir. 1994) (noting that Rule 702 prescribes a "liberal" policy for the admission of expert testimony); Fox v. Dannenberg, 906 F.2d 1253, 1256 (8th Cir. 1990) ("[A]n individual can qualify as an expert ... even though he may lack academic qualifications in the particular field of expertise.").

${ }^{57} 509$ U.S. 579, 585-95 (1993).

58526 U.S. 137, 147 (1999).

${ }^{59}$ See FED. R. EVID. 701; White v. Walker, 932 F.2d 1136, 1141 (5th Cir. 1991) (excluding lay opinion on child psychology). Rule 701 is itself a liberalizing rule, as is recognized in, for example, Staley v. Bridgestone/Firestone, Inc., 106 F.3d 1504, 1513 (10th Cir. 1997) (indicating that Rule 701 allows for "somewhat speculative" opinion).
} 
of the requirements for authentication, ${ }^{60}$ about limitations on the use of demonstrative evidence, ${ }^{61}$ and about numerous other less important exclusionary rules. In all of these instances the evidentiary rule operates to exclude otherwise relevant evidence, and for almost all of these rules the exclusion is typically explicitly justified in terms of avoiding the risk of misleading the jury or of preventing the jury from mis-assessing the actual value of the evidence. ${ }^{62}$ Thus, as a consequence of the assumed jury-dependence of this panoply of exclusionary rules, we have seen that judges sitting without juries often treat these exclusions and related requirements as being, at best, hints (or rules of thumb) about how much weight to give the evidence, rather than as genuine rules demanding categorical exclusion. ${ }^{63}$ We have seen that proposals to codify or formalize this state of affairs surface with considerable frequency. We have seen that the Federal Rules of Evidence have softened, compared to the situation existing at common law prior to enactment of the Rules, each of these rules of exclusion. And we have seen that the exclusionary rules are among the rules that no longer exist, or never existed in the first place, in juris-

\footnotetext{
${ }^{60}$ See FED. R. EvID. 901. Rules 902 and 903 both substantially liberalize the traditional authentication requirements. FED. R. EVID. 902 (listing documents that do not need extrinsic evidence of authenticity for admission); FED. R. EVID. 903 ("The testimony of a subscribing witness is not necessary to authenticate a writing unless required by laws of the jurisdiction ...."); see also United States v. Jimenez Lopez, 873 F.2d 769, 772 (5th Cir. 1989) (emphasizing that the listed forms of authentication in Rule 901 are not exclusive).

${ }^{61}$ See Richard O. LEMPERT ET AL., A MOdern APPROACH to EVIDENCE 1146 (3d ed. 2000) (noting that "[s]ome courts do not distinguish between real and demonstrative evidence").

${ }^{62}$ See, e.g., United States v. Daniels, 770 F.2d 1111, 1116 (D.C. Cir. 1985) (justifying exclusion of character evidence by reference to "fear that juries will tend to give it excessive weight"); GOLDMAN, supra note 19, at 294 (observing that evidence can be both relevant and misleading); MUELLER \& KIRKPATRICK, supra note 5, § 9.32, at 1050 (noting that demonstrative evidence may mislead juries); Richard D. Friedman, Minimizing the Jury Over-Valuation Concern, 2003 MiCH. ST. L. REV. 967, 967-68 (observing that the most common justification for excluding hearsay, character, and prior misconduct evidence is the fear that juries will overvalue such evidence).

${ }^{63}$ To make clear what is implicit in my entire analysis, I do not consider totally transparent (to their background justifications) rules of thumb (what some might call "guidelines") to be variants of (real) rules. See Frederick SCHAUER, Playing BY THE Rules: A PHILOSOPHICAL ANALYSIS OF RULE-BASED DECISION-MAKING IN LAW AND IN LIFE 104-11 (1991); Frederick Schauer, Exceptions, 58 U. CHI. L. REV. 871, 893-98 (1991). As the presence of rules of thumb in the act-utilitarian canon indicates, CONTEMPORARY UTILITARIANISM, supra note 28, a rule that can be set aside whenever its background justifications would indicate a contrary outcome is hardly a rule at all. And that is why the Free Proof tradition, my primary target here, is no less a nonrule tradition for its occasional employment of transparent or nonweighty heuristic rules.
} 
dictions without juries or whose recent use of the jury has been considerably diminished. Taken together, therefore, it is hard to escape the conclusion that Bentham's views are very much on the ascendancy, that much of the entire law of evidence is in decline, and that arguments based on the Free Proof approach are close to winning the day.

\section{RulES AND THE RULES OF EVIDENCE}

The question whether judges sitting without a jury should discard or relax the rules of evidence ${ }^{64}$ can be seen as but one manifestation of a set of larger and deeper issues about the role of rules in decision making. And one way of seeing this parallel is by imagining that the existing skepticism about the role of rules in epistemic decision making - the skepticism of Bentham, Thayer, Wigmore, and many contemporary trial judges-were to be applied to normative or prescriptive substantive legal rules. As act-consequentialists have long insisted, numerous subsidiary rules are best seen as heuristics, or rules of thumb, whose ultimate goal is to help us make those all-thingsconsidered decisions that will maximize utility (or some other ultimate value occupying a status equivalent to utility, but within a nonutilitarian, although still consequentialist, framework). ${ }^{65}$ For the committed but sophisticated act-consequentialist, rules have their place, but the decision maker must discard the indications of those rules when, all things (including the value of having a rule) considered ${ }^{66}$ following the rule will produce less utility (or whatever) than would be produced by a different decision. ${ }^{67}$

There are counterparts to this perspective within legal theory. Some of these counterparts are descriptive, and we associate many of the Legal Realists with the view that judges typically make what seem

\footnotetext{
${ }^{64}$ And thus also the question whether systems without juries should adopt rules of evidence, or develop more rules of evidence than they now have.

${ }^{65}$ See supra note 63. Sophisticated act-utilitarianism is developed or discussed in many of the contributions in CONTEMPORARY UTILITARIANISM, supra note 28.

${ }^{66}$ There are connections between this position and the view of evidence expressed in Richard A. Posner, An Economic Approach to the Law of Evidence, 51 STAN. L. REV. 1477, 1481-83 (1999).

${ }^{67}$ See Donald H. Regan, Authority and Value: Reflections on Raz's Morality of Freedom, 62 S. CAL. L. REv. 995, 1030 (1989) ("[I]f the authority is clearly in error, its directives are not binding."); Donald H. Regan, Law's Halo, in PHILOSOPHY AND LAW 15, 1625 (Jules Coleman \& Ellen Frankel Paul eds., 1987); J.J.C. Smart, Extreme and Restricted Utilitarianism, 6 PHIL. Q. 344, 348-49 (1956) (suggesting that it is illogical to obey a rule when breaking it would achieve a better result).
} 
to them to be the best all-things-considered decision, using specific rules of law as after-the-fact rationalizations rather than as being genuinely decision motivating or decision guiding. ${ }^{68}$ And others are normative, seeing in accounts as diverse as those of Ronald Dworkin ${ }^{69}$ and Michael Moore ${ }^{70}$ the efforts to see legal rules not as legal ends in themselves, but instead as potentially transparent and defeasible indicators of the larger and deeper goals that judges should strive to achieve, or of the larger and deeper rights that judges should seek to locate. $^{71}$

\footnotetext{
${ }^{68}$ The view that legal rules are deployed largely as ex post rationalizations for decisions reached on other grounds (which grounds might well include decisions on the basis of other rules, including prescriptive rules about policy or justice that are not part of the law as such) is the central empirical claim of Legal Realism. See JERome Frank, LAW AND THE MODERN MIND 130 (1930) (describing how a chief function of the law "is to enable the judges to give formal justifications ... of the conclusions at which they otherwise arrive"); K.N. LLEWELLYN, THE BRAMBLE BUSH: SOME LECTURES ON LAW AND ITS STUDY (1930); Joseph C. Hutcheson, Jr., The Judgment Intuitive: The Function of the "Hunch" in Judicial Decision, 14 CORNELL L.Q. 274, 278 (1929); Underhill Moore \& Charles Callahan, Law and Learning Theory: A Study in Legal Control, 53 YALE L.J. 1, 79 (1943). Although not all of Realism and not all of the writings of the major Realists fit this exact description, see WiLliam TWINING, KARL LlEWELlyn AND THE REALIST MOVEMENT 169 (1973) ("[L]aw and justice had no need at all to be in conflict or even in too much tension, but could instead represent a daily working harmony." (quoting Karl Llewellyn, The Common LaW Tradition: Deciding APPeAls 513 (1960))), the lack of decision-determining power for legal rules remains a defining characteristic of Realism, see Brian Leiter, Legal Indeterminacy, 1 LEGAL THEORY 481 (1995); Brian Leiter, Legal Realism and Legal Positivism Reconsidered, 111 ETHICS 278 (2001); John Henry Schlegel, American Legal Realism and Empirical Social Science: The Singular Case of Underhill Moore, 29 Buff. L. REv. 195, 239 (1980); Charles M. Yablon, Justifying the Judge's Hunch: An Essay on Discretion, 41 HASTINGS L.J. 231, 236 (1990) (arguing that realists "denied that the actions of legal decisionmakers were the determinate results of applying general legal rules found in statutes or appellate cases").

${ }^{69}$ See RONALD DWORKIN, LAW'S EMPIRE 15-20 (1986); RONALD DWORKIN, TAKING RIGHTS SERIOUSLY (1977).

${ }^{70}$ See Michael S. Moore, The Interpretive Turn in Modern Theory: A Turn for the Worse?, 41 STAN. L. REV. 871, 956 (1989) ("Anglo-American legal practice, which is largely interpretive, cannot be insulated from external questions."); Michael S. Moore, A Natural Law Theory of Interpretation, 58 S. CAL. L. REV. 277, 383-84 (1985) (claiming that even after a judge has looked at the "ordinary meaning" of a legal rule, she must then decide whether her initial "interpretation serves the purpose of the rule in question”); Michael S. Moore, The Semantics of Judging, 54 S. CAL. L. REV. 151, 278 (1981) (stating that judges should not just look at laws in a "literal" sense, but look behind them, in light of their "ethical intuitions about what, in rules of this sort, the word ought to mean").

${ }^{71}$ In fact, both Dworkin and Moore, albeit in slightly different ways, reach this result by indirection, arguing that there is a difference between the superficial rule-the seeming meaning of the words of the rule formulation-and the deeper or "real" meaning of the rule itself. DWORKIN, LAW's EMPIRE, supra note 69, at 16-17; Moore, The Semantics of Judging, supra note 70, at 278; see also David O. Brink, Legal Theory, Legal
} 
The foregoing paragraph contains more than a bit of a caricature, but that is my basic point. Neither the Realists (or at least most of them) nor Dworkin nor Moore believe that substantive legal rules do not comprise in important ways fixed points, such that a judge who thought of them as simply rules of thumb would remain faithful to the judicial office. We expect judges to take substantive legal rules seriously, largely because we see such rules as serving important functions in practical reasoning that would be poorly served were judges to see themselves as simply making what seemed to them to be the best allthings-considered decision. Indeed, even were that the goal, we have a healthy enough appreciation of the variability of views and values and talents among actual judges that we see legal rules as cabining some of this variation by holding judges to the rules of law even when those rules might generate morally, politically, or pragmatically suboptimal results. ${ }^{72}$

To the extent that any of this resonates with respect to the substantive rules of law in general, however, then it is at least arguable that it resonates pro tanto with respect to that set of procedural or epistemic rules that we label as the law of evidence. If we think that normal substantive legal rules have a point other than as transparent heuristics, then we might well think that the rules of evidence also have a point, and not just as epistemic rules of thumb. Many or most of the reasons that lead us to abjure the $q^{\prime} a d i{ }^{73}$ or the unconstrained pragmatist, with respect to normative determinations should lead us to have largely commensurate worries with respect to factual ones. Wary of Platonic guardians, we impose on our judges more or less

Interpretation, and Judicial Review, 17 PHIL. \& PUB. AFF. 105, 125 (1988) (arguing that we should see laws as "human artifacts" and thus look at the "reasons, purposes, and intentions of those who enacted the law" in addition to the actual "meaning of the words"). For present purposes, however, we can let this complication pass.

${ }^{72}$ On the larger distinction between rule-based and all-things-considered decisions, see LARRY AleXANDER \& EMIly SHERwin, The Rule of Rules: Morality, Rules, ANd the Dilemmas of LaW (2001); Frederick Schauer, Playing by the RULES, supra note 63 , at 77-78.

${ }^{73}$ The reference here is to Max Weber's (largely inaccurate, as a matter of Islamic law) characterization of the Islamic q'adi judge (which Weber spelled "khadi") as the ultimate embodiment of discretionary and contextual decision making. See MAX WEBER, LAW IN ECONOMY AND SOCIETY 351 (Max Rheinstein ed., Edward Shils \& Max Rheinstein trans., 1967) ("[Khadi justice] decides cases ... non-formalistically and in accordance with concrete ethical or other practical value-judgments."); see also ANTHONY T. KRONMAN, MAX WEBER 76-77 (1983) (describing Weber's interpretation of so-called "khadi justice" as "adjudication of a purely ad hoc sort in which cases are decided on an individual basis and in accordance with an indiscriminant mixture of legal, ethical, emotional and political considerations"). 
concrete substantive rules of law, but the worries about Platonic guardians hardly evaporate when we ask them to reach factual rather than normative conclusions. And if this is so, then there are reasons to fear a Free Proof tradition that turn out to be not that much different from the reasons to fear a Free Law ${ }^{74}$ tradition.

As noted above, ${ }^{75}$ the issue bears some affinity with a plausible rule-consequentialist tradition dating back to John Stuart Mill, relying heavily on Henry Sidgwick, and having its best-known more-or-less modern embodiment in the later work of R.M. Hare. ${ }^{76}$ As David Lyons has demonstrated, rule-consequentialism collapses into actconsequentialism if we assume that the maker of the rule and follower of the rule are the same agent. ${ }^{77}$ But for Mill in chapter 5 of Utilitarianism, the argument for encouraging people to pursue justice as an end in itself resides in the possibility that pursuing justice will lead to greater utility than will encouraging ordinary people to pursue utility directly. ${ }^{78}$ Sidgwick expanded on these themes, in ways that attracted the epithet "Government House utilitarianism," "79 and Hare developed the idea further with his unfortunately labeled distinction between "archangels" and "proles." But although the labels were unfortunate, the idea is important, because it captures the insight that there are distinctions that can be understood and drawn by some people under some conditions that are not distinctions that other people can reasonably be expected to understand, internalize, and apply. ${ }^{8}$

The relevance of this tradition to our problem should now be obvious. For Bentham, Thayer, and Wigmore, for many of their contemporary academic followers, and for many members of the contem-

\footnotetext{
${ }^{74}$ There is, of course, a tradition with just that name, see generally James E. Herget \& Stephen Wallace, The German Free Law Movement as the Source of American Legal Realism, 73 VA. L. REV. 399, 407-19 (1987), but I make no claim of any connections here.

${ }^{75}$ See supra note 28.

${ }^{76}$ For a more recent expression, see CONRAD D. JOHNSON, MORAL LEGISLATION: A LEgal-Political MODEL FOR INDIRECT CONSEQUENTIALIST REASONING (1991); see also Larry Alexander, Pursuing the Good-Indirectly, 95 ETHICS 315, 318 (1985); R.B. Brandt, Faimess to Indirect Optimific Theories in Ethics, 98 ETHICS 341, 342 (1988).

${ }^{77}$ DAVID LYONS, FORMS AND LiMITS OF UTILITARIANISM (1965).

${ }^{78}$ Mill, supra note 28, at 300 ("[ J] ustice is a name for certain moral requirements, which, regarded collectively, stand higher in the scale of social utility, and are therefore of more paramount obligation, than any others ....").

${ }^{79}$ BERNARD WILLIAMS, The Point of View of the Universe: Sidgwick and the Ambitions of Ethics, in MAKING SENSE OF HuMANITY AND OTHER PHILOSOPHICAL PAPERS, 1982-1993 at 153,166 (1995).

${ }^{80}$ See supra note 28.

${ }^{81}$ See Frederick Schauer, Slippery Slopes, 99 HARV. L. REv. 361, 380-81 (1985).
} 
porary trial bench, judges are the archangels and jurors the proles. Rules are for other and weaker people. Conversely, therefore, those who perceive themselves as possessing greater wisdom, training, and insight tend also to perceive themselves as having far less need for the rules that society often employs as second-best strategies in order that third-best decision makers will not persistently make fourth-best decisions. So when the proles are not part of the picture, Bentham and his successors appear to have believed, the reasons for rules are vastly diminished, and the archangels can make the best all-thingsconsidered epistemic decisions in much the same way as they might make the largely rule-free all-things-considered substantive and normative ones.

I do not want to press the parallel too far, but the similarities are nonetheless suggestive. And what the parallels most suggest is that the question of Free Proof, even though it is about facts and not about substantive prescriptions, is largely a question about rules, and about when it might be valuable to think of rules as decision-making devices that are designed for worse rather than for better decision makers. To the extent that we really do think that judges are simply better at many things than juries, it would follow that this might apply as much to factual determinations as to the question of how to resolve the disputes and make the decisions that those facts raise. But if we truly believed this, then we would have far fewer substantive legal rules than we actually now do have, and a far more casual (or "rule of thumb") attitude towards the substantive rules that we have than is in fact the case. Thus, our existing stock of substantive legal rules and our actual perspective on the force of those rules suggest that we believe that such rules serve a valuable function in, among other things, channeling and constraining judicial decisions, reducing the variability among judges and their decisions, and adding important elements of predictability and reliance to the legal and judicial processes.

It remains possible that none of these considerations leading to the size and weight of our stock of prescriptive legal rules apply to factual determinations. It is far more plausible to believe, however, that many of the same considerations apply to factual determinations as to normative ones. There may well be differences, to be sure, but it appears likely that there are far more similarities between ordinary prescriptive legal rules and the epistemic rules of evidence than most judges and most commentators have historically believed, and believe even now. To the extent that this is so, the burden of proof shifts to the commentators and judges to show that the reasons for having le- 
gal rules in general do not apply when those rules shape and constrain the fact-finding process. ${ }^{82}$ And we have little reason to believe that this burden of proof has yet been carried.

\section{ON THE RELATIVE CAPACITIES OF JUDGES AND JURIES}

There is occasional resistance in the literature to attributing much of the initial ascendancy and subsequent decline in the power of the exclusionary rules of evidence to the alleged cognitive deficiencies of jurors. This resistance-criminal cases with constitutional dimensions aside $^{83}$-is typically some variation on the basic theme of "juries are not as dumb as you think they are, ${ }^{84}$ often (and admirably) supported

\footnotetext{
${ }^{82}$ An important contemporary tradition in evidence scholarship urges rejection of the traditional atomistic/Bayesian/incremental approach to admission and exclusion of items of evidence in favor of a holistic and coherence-based approach, which is argued to be more compatible with the way in which people actually reason about facts. See, e.g., Ronald J. Allen, Factual Ambiguity and a Theory of Evidence, 88 Nw. U. L. REV. 604,629 (1994) ("[E]ach decision is a unique function of the interaction of the parties' sense of ambiguity with the fact finders' understanding of it that remains rational notwithstanding each decision's uniqueness and our inability to capture the decision process in a set of necessary and sufficient rules."); Ronald J. Allen \& Brian Leiter, Naturalized Epistemology and the Law of Evidence, 87 VA. L. REV. 1491, 1550 (2001) (criticizing evidence scholarship for clinging to "[a] priori formalisms"); Michael S. Pardo, Comment, Judicial Proof, Evidence, and Pragmatic Meaning: Toward Evidentiary Holism, 95 NW. U. L. REv. 399, 440 (2000) ("The empirical and analytical work suggests a shift from this parataxic approach to a more holistic perspective."); Dan Simon, A Third View of the Black Box: Cognitive Coherence in Legal Decision Making, 71 U. CHI. L. REv. 511, 560-62 (2004) (suggesting that the "relative plausibility theory" is more consistent with human decision making than the Bayesian approach). Such perspectives may well be sound, but it is less clear than some of their proponents appear to believe that they entail acceptance of variants on the Free Proof idea. See, e.g., Allen, Factual Ambiguity and a Theory of Evidence, supra, at $631 \mathrm{n} .82$ (indicating that a theory of Free Proof is "implicit" in his holistic account). Any holistic or coherence-based approach must distinguish between identifying the initial field of items on which the reasoning process is applied and specifying the method of reasoning that will be applied to that field. Evidentiary holism addresses the latter issue, but is in fact agnostic on the question of how the initial field is selected. As a result, a rule-based approach to deciding what constitutes the field is fully consistent with a holistic approach to what should be done with that field. And as long as a rule-based field selection is compatible with a holistic method of reaching epistemic conclusions from that field, nothing about epistemic holism either presupposes or entails acceptance of Free Proof-like principles and rejection of exclusionary epistemic or evidentiary rules.

${ }^{83}$ The most noteworthy example being the constitutionalization of some aspects of the hearsay rule after Crawford $v$. Washington, 541 U.S. 36, 68 (2004).

${ }^{84}$ See, e.g., Friedman, supra note 62, at 985 (arguing that "the over-valuation concern should [not] lead to exclusion of . . . evidence"); Bernard Grofman \& Heathcote W. Wales, Modeling Juror Bias, 5 LEgAL THEORY 221, 224 n.10 (1999) (criticizing the existing exclusionary rules of evidence as based on "paternalistic notions about the
} 
with some empirical (usually experimental) evidence. ${ }^{85}$ But although such arguments seek to shift the terms of the debate, they do not seek to alter the current trend in evidence law, for they support rather than resist the general movement in favor of greater admissibility. After all, if juries are less dumb than we thought they were, and if juror dumbness is the primary basis for many of the traditional exclusions, then discovering that jurors are not so dumb supports the admission of previously excluded evidence and the relaxation of the traditional rules against hearsay, character, past acts, nonoriginal documents, and much else.

Yet although we increasingly see the "juries are not as dumb as you think they are" argument for allowing lay jurors to hear what judges sitting without juries often take it upon themselves to hear, we still do not see much of the "judges are not as smart as they think they are" argument, an argument that, to the extent it is sound, suggests a quite different conclusion-that judges, rather than seeking to relax the rules of evidence for themselves, should instead impose on themselves (or have imposed upon them) many of the same rules of exclusion that they routinely apply to the juries they manage and instruct. This latter argument sails directly into the prevailing winds of evidence law, for rather than seeking to ameliorate the effects of the traditional exclusionary rules by relaxing those rules when juries do not

competence of jurors to evaluate evidence”); Nance, supra note 16, at 229 (arguing that justification for exclusionary rules of evidence should not primarily focus on overblown "concerns about the irrational behavior of weak-minded lay jurors"); Richard D. Friedman, Anchors and Flotsam: Is the Law of Evidence "Adrift"?, 107 YALE L.J. 1921, 196667 (1998) (book review) (suggesting that justiciable exclusionary evidentiary rules are justified not by juror cognitive deficiencies but instead by conceptions of individual rights).

${ }^{85}$ See Dale A. Nance \& Scott B. Morris, Juror Understanding of DNA Evidence: An Empirical Assessment of Presentation Formats for Trace Evidence with a Relatively Small Random-Match Probability, 34 J. LEGAL STUD. 395, 435 (2005) (concluding, after empirical study, that jurors "generally make reasonable use of complex material" (quoting Neil Vidmar \& Shari S. Diamond, Juries and Expert Evidence, 66 BROOK. L. REV. 1121, 1166 (2001))); Dale A. Nance \& Scott B. Morris, An Empirical Assessment of Presentation Formats for Trace Evidence with a Relatively Large and Quantifiable Random Match Probability, 42 JURIMETRICS J. 403, 444 (2002) (countering concerns that juries overvalue scientific evidence with research suggesting that juries actually tend to undervalue such evidence). For a summary of some of the social science evidence, much (but hardly all) of which supports the traditional skepticism about juries, see Ehud Guttel, Overcorrection, 93 GEO. L.J. 241, 253-60 (2004); Daniel A. Krauss \& Bruce D. Sales, The Effects of Clinical and Scientific Expert Testimony on Juror Decision Making in Capital Sentencing, 7 PSYCHOL. PUB. POL’Y \& L. 267, 274 (2001). 
sit, it seeks to strengthen those rules even when allegedly cognitively superior judges are sitting as the triers of fact.

Although I put the issue in terms of "smart" and "dumb," these words are only a rhetorical flourish. The precise claim here is that even judges are often afflicted with the kinds of cognitive failings that juries are ${ }^{86}$ and that many of the same reasons that exist for imposing second-order exclusionary (or other) rules on juries' first order epistemological assessments also apply to the arguments for imposing second-order rules on the first-order epistemological assessments of judges.

This argument is best put forth as a hypothesis subject to further testing, for, as yet, we have only a limited stock of such tests. What we know about jury behavior we know from experiments on mock (and occasionally real $^{87}$ ) juries, ${ }^{88}$ or from laboratory experiments on ordi-

\footnotetext{
${ }^{86}$ Cognitive failings include not only the failures of overvaluation, but also the failures of undervaluation. See Nance \& Morris, Juror Understanding, supra note 85, at 397 (recognizing the risk that jurors might both overvalue and undervalue scientific evidence). And although an exclusionary rule would be a bizarre remedy for the failing of undervaluation, the larger point is that even a failure of undervaluation might usefully be corrected by some sort of second-order rule whose existence and power would be in tension with the Free Proof tradition. Even if that second-order rule is not an exclusionary one, it still might inflate (or decrease) the weight of admitted evidence, or include that which would otherwise be excluded. On inclusionary rules, see EDWARD W. CLEARY ET AL., MCCORMICK ON EVIDENCE $\$ 24$, at 56-57 (3d ed. 1984) (distinguishing "wide-open" and "restrictive" rules regarding cross-examination); SCHAUER, Playing BY THE RUles, supra note 63, at 91-92; Dale A. Nance, Verbal Completeness and Exclusionary Rules Under the Federal Rules of Evidence, 75 TEX. L. REV. 51, 52 (1996) (describing the "rule of completeness" which "unlike almost all other admissibility rules ... is inclusionary"). So even if the failings of jurors are sometimes not the failings of overvaluation, the real question is whether we have reason to believe that any of the cognitive failings we observe in jurors are significantly less present in judges. And if we do not have good reason to draw this distinction, then the larger issue, and the one discussed at length above in Part III, is whether there is justification for treating inquiry about facts as a substantially less rule-based affair than inquiry about the applicable norms.

${ }^{87}$ E.g., Shari Seidman Diamond et al., Revisiting the Unanimity Requirement: The Behavior of the Non-Unanimous Civil Jury, 100 NW. U. L. REV. 201 (2006) (reporting study of actual juries in fifty Arizona civil trials).

${ }^{88}$ E.g., Richard R. Izzet \& Walter Leginski, Group Discussion and the Influence of Defendant Characteristics in a Simulated Jury Setting, 93 J. SOC. PsYCHOL. 271, 273-75 (1974) (describing a mock jury study using undergraduates in an introductory psychology course). Comprehensive surveys include Guttel, supra note 85, at 253-60 (discussing experimental evidence that juries are often unable to ignore inadmissible evidence); Robert MacCoun, Inside the Black Box: What Empirical Research Tells Us About Decisionmaking by Civil Juries, in VERDICT: ASSESSING THE CIVIL JURY SYSTEM 137 (Robert E. Litan ed., 1993) (evaluating various methods used to study juror decisionmaking in civil actions); Michael T. Nietzel et al., Juries: The Current State of the Empirical Literature,
} 
nary people (who are usually not so ordinary, but are instead college sophomores taking psychology courses ${ }^{89}$ ) that are typically extrapolated to support claims about the kinds of ordinary people who wind up on juries. ${ }^{90}$ But implicit in the existing literature and its methodologies is the view that while such experimental subjects are more or less representative of the ordinary people who sit on juries, they are not at all representative of judges. Nor is there a body of research directed precisely at the methodological question of whether college sophomores are as representative of judges as fact finders as they are of the ordinary reasonable person ${ }^{91}$ as a fact finder. In the same vein, we still wait for experiments holding constant the nature of the evidence and manipulating (in the technical sense) the education, intelligence, role, and training of the fact finder in order to determine whether what we know and assume about jurors might apply to judges as well. And in the absence of such experimental empirical conclusions, we assume that judges are less prone than juries to the cognitive and decision-making failures we worry about in jurors, possibly because judges are smarter, possibly because they are better educated, possibly because of their greater experience in hearing testimony and finding facts, ${ }^{92}$ and almost certainly because of their legal training and legal role-internalization. ${ }^{93}$

in PSychology and Law: The StATE OF THE Discipline 23 (Robert Roesch et al. eds., 1999) (providing overview of learning on juror behavior derived from empirical research); see also GOLDMAN, supra note 19, at 298-99 (describing study in which mock jurors watched a videotaped reenactment of a trial).

${ }^{89}$ Who Needs Real Managers When You've Got Fraternity Boys?, PsyCHOL. TODAY, Feb. 1998, at 26, 26.

${ }^{90}$ See ReID Hastie ET AL., Inside the Jury 38-41 (1983) (explaining benefits and disadvantages of using mock jurors in studies); Nancy Pennington \& Reid Hastie, Practical Implications of Psychological Research on Juror and Jury Decision Making, 16 PERSONALITY \& SOC. PSYCHOL. BULL. 90, 94 (1990) (comparing studies using undergraduates against those using individuals from actual jury pools); Nancy Pennington \& Reid Hastie, Juror Decision-Making Models: The Generalization Gap, 89 PsYCHOL. Bull. 246, 279-84 (1981) (evaluating methodologies for research on jury decision making). An interesting example of the phenomenon is Fred E. Inbau, Lay Witness Identification of Handwriting (An Experiment), 34 ILL. L. REV. 433, 434 (1939), which used an experiment conducted on Northwestern University law professors to draw conclusions about the behavior of lay jurors.

${ }^{91}$ Or, as the English so quaintly put it, "the man on the Clapham omnibus." E.g., McQuire v. W. Morning News Co., [1903] 2 K.B. 100, 109.

${ }_{92}$ And possibly because they are like us.

93 See Gregory Mitchell, Mapping Evidence Law, 2003 MiCH. ST. L. REv. 1065, 1122 (differentiating the quality of decisions made by judges and juries by referencing the "repeat player" status of judges and the higher standard of accountability placed on them). Kalven and Zeisel identified a divergence between the results reached by juries 
In the absence of much empirical evidence, therefore, and with the hope that there will be more of just these kinds of experiments, a few observations are in order. First is that the empirical evidence that does exist supports the "judges are not as smart as they think they are" view, although primarily in the context of the ability to disregard constitutionally inadmissible evidence rather than in the more germane (here) context of overvaluing, or otherwise mis-assessing, actually probative evidence. ${ }^{94}$ In addition, although we may not know much about the actual cognitive abilities of judges as compared to juries, we do know quite a bit about the tendency of people, and especially professionals, to overestimate their own cognitive abilities. And what we know is not encouraging. Consider, for example, the research on actuarial versus clinical decision making. ${ }^{95}$ In numerous contexts, in-

and the results on the same facts reached by judges in HARRY KALVEN, JR. \& HANS Zeisel With THOMAS CALlaHAN \& PHILIP ENNIS, THE AMERICAN JuRY 56 (1966) (finding that judges and juries disagree $24.6 \%$ of the time), but their methodology may have overestimated the degree of divergence, and in any event does not allow a conclusion about whether the divergence was attributable to mistakes by juries or mistakes by judges. See Goldman, supra note 19, at 312 (noting that the Kalven and Zeisel study was limited to criminal cases and failed to identify how errors were distributed between judges and juries). Indeed, because the judges were more inclined to convict in criminal cases than juries, one explanation is that judges were more inclined to go beyond the evidence and rely on their own beliefs about how the defendant wound up in the dock in the first place.

${ }^{94}$ Andrew J. Wistrich, Chris Guthrie \& Jeffrey J. Rachlinski, Can Judges Ignore Inadmissible Information? The Difficulty of Deliberately Disregarding, 153 U. PA. L. REV. 1251, 1330-31 (2005) (concluding that judges are frequently unable to ignore inadmissible information in making decisions); see also Chris Guthrie, Jeffrey J. Rachlinski \& Andrew J. Wistrich, Inside the Judicial Mind, 86 CORNELL L. REV. 777, 821 (2001) ("Like the rest of us, [judges] use heuristics that can produce systematic errors in judgment."); Paul H. Robinson \& Barbara A. Spellman, Sentencing Decisions: Matching the Decisionmaker to the Decision Nature, 105 COLUM. L. REV. 1124, 1138-43 (2005) (discussing differences and similarities between judge and jury fact-finding abilities).

95 See, e.g., John Monahan, Predicting Violent BehaVior: An Assessment of CLINICAL TECHNIQUES 97 (1981) (claiming that studies have repeatedly shown actuarial predictions to be superior to clinical predictions); Stephen D. Gottfredson, Statistical and Actuarial Considerations, in THE PREDICTION OF CRIMINAL VIOLENCE 71, 75 (Fernaud N. Dutile \& Clem H. Foust eds., 1987) (arguing that statistical models tend to more accurately predict behavior than clinical judgments); N. Zoe Hilton \& Janet L. Simmons, The Influence of Actuarial Risk Assessment in Clinical Judgments and Tribunal Decisions About Mentally Disordered Offenders in Maximum Security, 25 L. \& HuM. BEHAV. 393, 405 (2001) (recommending that actuarial assessments be substituted for clinical judgments in decisions to release mentally ill offenders); Ann Ward \& John Dockerill, The Predictive Accuracy of the Violent Offender Treatment Program Risk Assessment Scale, 26 CRIM. JUST. \& BEHAV. 125, 136-37 (1999) (presenting advantages of an actuarial model for identifying violent offenders). The opposing view, a decidedly minority one, is represented in, for example, Thomas R. Litwack, Actuarial Versus Clinical Assessments of Dan- 
cluding release from prison on parole, sentencing to probation rather than prison, release from institutions of those who have been civilly committed for reasons of risks of danger to themselves and others, and many more, it is important to be able to predict future dangerousness. One way of doing this is actuarial, with the predictor asked to identify a small number of readily observable features whose presence has in the past been shown to be a non-spurious predictive factor with respect to future dangerousness. And the other way is clinical, with trained professionals-psychologists, psychiatrists, social workers, etc. -conducting face-to-face interviews and then making their best qualitative, all-things-considered judgment about future dangerousness.

When such comparisons are drawn, almost all of the existing research indicates that actuarial assessments of dangerousness are typically superior to clinical assessments, and that one reason for this, although not the only reason, is that professionals typically overestimate the power of their own professional skills, the reliability of their own judgments, and the strength of their ability to assess a particular situation. ${ }^{96}$ If we can extrapolate from this and related research, ${ }^{97}$ we might have reason to believe that judges will typically overestimate their own ability to assess facts, their capacity to rise above the cognitive failings of lesser mortals, and thus their own lack of need for the kinds of exclusions (or, in theory, inclusions or weight-increasers ${ }^{98}$ ) that are represented by many of the rules of evidence. ${ }^{99}$ So even if, for the sake of argument, we assume that judges are indeed better than juries at not overestimating the value of hearsay evidence, at recogniz-

gerousness, 7 PSYCHOL. PUB. POL'Y \& L. 409, 437-38 (2001) (arguing that actuarial models are not reliable enough to replace clinical assessments).

${ }^{96}$ See, e.g., Colin Camerer \& Dan Lovallo, Overconfidence and Excess Entry: An Experimental Approach, 89 AM. ECON. REV. 306, 311 (1999) (finding that subjects generally overestimate their skills relative to their competitors'); Leilani Greening \& Carla C. Chandler, Why It Can't Happen to Me: The Base Rate Matters, but Overestimating Skill Leads to Underestimating Risk, 27 J. APPLIED SOC. PSYCHOL. 760, 774 (1997) (finding that most subjects believed that their skill levels were better than average); Markus Glaser, Thomas Langer \& Martin Weber, Overconfidence of Professionals and Lay Men: Individual Differences Within and Between Tasks? 26 (Apr. 26, 2005) (unpublished manuscript), available at http://papers.ssrn.com/abstract=712583 (concluding, after empirical study, that professionals tend to be overconfident when compared with a control group of students).

${ }^{97}$ Some of the research is engagingly described and applied in JAMES SUROWIECKI, THE WiSDOM OF CROWDS 31-36 (2004).

${ }^{98}$ See supra note 86.

${ }^{99}$ I assume, perhaps counterfactually, that judges are no more likely to over-assess their own abilities than are other professionals. 
ing the risks of non-original documents, at taking alleged expertise with a grain of salt, at giving character and prior acts showing a propensity to commit some current act their proper weight, and so on, it appears that we also have reason to believe that the gap between jurors and judges in this regard, even if it does exist, will be systematically over-assessed by the judges themselves.

In addition, some of the cognitive failings that undergird the exclusionary rules of evidence are ones that may well resist just the kind of corrections that judges believe they are able on the basis of their training and experience to make. Although the first wave of heuristics and biases research-by Daniel Kahneman and Amos Tversky, most prominently, but followed by many others as well ${ }^{100}$ - was focused on identification of the rationality deficits of decision makers, subsequent waves have also looked at the extent to which some of these mistakes can be completely or largely eliminated by simple awareness of the bias or by somewhat more extensive "re-education." 101 And so, although the research indicates that awareness of the bias can eliminate some biases-most of the framing biases, for example-the same research program also indicates that other biases are quite resistant to a range of awareness-based de-biasing techniques-anchoring, for ex-

${ }^{100}$ Amos Tversky \& Daniel Kahneman, Judgment Under Uncertainty: Heuristics and Biases, in JUDGMENT UNDER UNCERTAINTY: HEURISTICS AND BIASES 3 (Daniel Kahneman, Paul Slovic \& Amos Tversky eds., 1982); see also ScotT Plous, The Psychology OF Judgment ANd Decision Making (1993); Choices, VAlues, and Frames (Daniel Kahneman \& Amos Tversky eds., 2002); Jeffrey J. Rachlinski, Heuristics and Biases in the Courts: Ignorance or Adaptation, 79 OR. L. REv. 61, 102 (2000) (discussing the problem of "congnitive illusions" in legal decision making). There is an emerging skeptical tradition about this entire line of research, see, e.g., GERD GIGERENZER, CALCUlATED Risks: HOW TO KNOW WHEN Numbers DeceIve YOU (2002); Gerd Gigerenzer \& Daniel G. Goldstein, Reasoning the Fast and Frugal Way: Models of Bounded Rationality, 103 PSYCHOL. REV. 650, 651 (1996) (advocating a theory of "bounded rationality" instead of the "heuristics-and-biases view"); G. Gigerenzer, The Bounded Rationality of Probabilistic Mental Models, in Rationality: Psychological And Philosophical PerSPECTIVES 284, 297-301 (K.I. Manktelow \& D.E. Over eds., 1993) (challenging the notion of an "overconfidence bias"); Gregory Mitchell, Why Law and Economics' Perfect Rationality Should Not Be Traded for Behavioral Law and Economics' Equal Incompetence, 91 GEO. L.J. 67, 138-39 (2002) (concluding that behavioral scientists often make inaccurate assumptions in their study of human judgment), but, because even the skeptical tradition values the use of rules and heuristics, the question of whether certain heuristics are examples of rationality or irrationality is not especially germane to my argument here.

${ }^{101}$ See Guthrie et al., Inside the Judicial Mind, supra note 94, at 822-25 (explaining that judges could be taught to identify and address their congitive biases by considering more perspectives, limiting the use of heuristics, and avoiding specific cognitive illusions). 
ample. ${ }^{102}$ As a result, not only will some of the cognitive problems that the rules of evidence are designed to guard against not be dramatically different for judges and jurors, ${ }^{103}$ and not only will some of them resist the kind of awareness-based de-biasing that is implicit in the judge-juror distinction, but the same pathologies that lead judges to believe they are not subject to juror pathologies will lead those same judges to believe, often erroneously, that they are especially able, as a result of awareness, to eliminate what few biases they believe they have.

Finally, it is not irrelevant that the judges who in a nonjury trial must determine the facts are the same ones who must make all of the legal rulings and all of the procedural rulings, and thus who must, in the final analysis, simply decide the case. Although few are so naive as to believe that jurors find facts without regard to the ultimate outcome, one important Realist message is that even judges make their intermediate or nonultimate determinations with some awareness of how these determinations will affect their own view of who, at the end of the day, ought to win the case. ${ }^{104}$ Now of course this Realist claim is an empirical one, ${ }^{105}$ and it is possible that the claim is mistaken for many or even most judges. But, insofar as the claim is sound-Karl

${ }^{102}$ See, e.g., Timothy Wilson et al., A New Look at Anchoring Effects: Basic Anchoring and its Antecedents, 4 J. EXPERIMENTAL PSYCHOL.: GEN. 387, 397 (1996) (revealing that study participants continued to exhibit anchoring, even when forewarned about anchoring effects).

${ }^{103}$ See Jon D. Hanson \& Douglas A. Kysar, Taking Behavioralism Seriously: The Problem of Market Manipulation, 74 N.Y.U. L. REV. 630, 633 (1999) (observing that cognitive biases "are not limited to the uneducated or unintelligent, and . . . are not readily capable of being unlearned").

${ }^{104}$ This perspective is central in much of the Realist canon. See, e.g., Frank, supra note 68 , at 131 (indicating that a judge's decision may be tailored to be consistent with his view of "the case before him"); Jerome Frank, Are Judges Human? Part I: The Effect on Legal Thinking of the Assumption that Judges Behave Like Human Beings, 80 U. PA. L. REv. 17, 47 (1931); Jerome Frank, Are Judges Human? Part II: As Through a Class Darkly, 80 U. PA. L. REV. 233, 242 (1931); Karl N. Llewellyn, Remarks on the Theory of Appellate Decision and the Rules and Canons About How Statutes Are To Be Construed, 3 VAND. L. ReV. 395, 398 (1950) (noting that it "makes a tremendous difference" whether a court responds more strongly to its "sense of the type of situation" or its "sense of a particular controversy between particular litigants"); Max Radin, Statutory Interpretation, 43 HARV. L. REV. 863, 881 (1930). On the potentially distorting effect of the pressure to decide the immediate case correctly, see Frederick Schauer, Do Cases Make Bad Law?, 73 U. CHI. L. REV. 883 (2006).

${ }^{105}$ See Brian Leiter, Legal Realism and Legal Positivism Reconsidered, 111 ETHICS 278, 279 (2001) ("The real dispute between Realism and Positivism . . . exists at the empirical level ....”); Brian Leiter, Realism, Hard Positivism, and Conceptual Analysis, 4 LEGAL THEORY 533, 547 (1998) (same). 
Llewellyn often focused on the power of the particular ${ }^{106}$ and Jerome Frank's commitment to the inevitability of particularism was considerably stronger still ${ }^{107}$ - then the lesson is that potentially distorted intermediate rulings may increase as the decision-making responsibilities about the admissibility of evidence and about the ultimate resolution of the case are merged. If there is a reason for at times requiring jurors to answer special interrogatories in addition to (or occasionally instead of) delivering general verdicts, then that same reason may caution against assuming that a judge in charge of all of the decisions in some case will make intermediate rulings undistorted by that judge's view of the proper outcome for the case as a whole. ${ }^{108}$ And insofar as that risk is real, then one way of understanding the occasionally formal, rigid, and mechanical application of the rules of evidence is to encourage a separation of functions across, and at times even within, decision makers. The judge who is required to enforce the rules of evidence on herself ${ }^{109}$ is a judge who might in an ideal world be able to function simultaneously as, in Hare's terms, archangel and prole. ${ }^{110}$ This is the judge who can screen herself off from just the kinds of facts that might in a perfect world produce a more accurate factual determination, but who in an imperfect or second-best world might make better decisions under circumstances in which there are things-and relevant things at that-that she simply does not know. But whether real judges can act this way in practice-whether real judges can stop thinking about pink elephants-is an empirical question whose answer is quite likely to be "rarely."

\section{But WhICH RULES?}

The conclusion of the foregoing analysis is simply stated: there appears to be more justification for a rule-based approach to evidence

${ }^{106}$ TwINING, supra note 68, at 369 (suggesting that attention to "the actual and the particular" was essential to Llewellyn's realism).

${ }^{107}$ See FRANK, supra note 68, at 101 ("Judicial judgments . . are worked out backward from conclusions ....").

${ }^{108}$ See generally Edmund M. Morgan, A Brief History of Special Verdicts and Special Interrogatories, 32 YALE L.J. 575 (1923). Perhaps the most famous special interrogatory case is the reversal of the conspiracy conviction of Dr. Benjamin Spock because the trial judge, in a criminal case, had impermissibly used special interrogatories as a way of avoiding the possibility of jury nullification. United States v. Spock, 416 F.2d 165, 180-91 (1st Cir. 1969).

109 See generally Thomas C. Schelling, Enforcing Rules on Oneself, 1 J.L. ECON. \& ORG. 357 (1985).

${ }^{110}$ HARE, supra note 28 , at $44-45$. 
than is accepted nowadays, and the idea of Free Proof may have more cognitive and epistemic disadvantages than Bentham thought almost two centuries ago and than Bentham's numerous academic and judicial followers seem to think now. ${ }^{111}$ But that the law of evidence should plausibly be a rule-based enterprise says nothing about what those rules should be. More to the point, the conclusion that we should have (intrinsic as well as extrinsic) rules of evidence does not entail the conclusion that we should have the intrinsic rules of evidence that we have now.

Although the argument for a rules-based approach to evidence leaves open the question of what those rules should be, there is also a rule-based argument that those rules should be substantially the rules we happen to have now, warts and all. Once we appreciate that a principal argument for rules derives from the advantages of having readily accessible and easily understandable indicators of deeper but harder-to-apply primary considerations, we can see that many of these advantages may well exist in an entire set of rules simply because of their existence. The very existence of the full set of evidence rules we happen to possess breeds a familiarity that increases understanding, and has developed in such a way over time that the common law process has served to remove many of the most obvious defects. Thus, if a large part of the case for individual rules is that the mistakes consequent from the under- and overinclusiveness of crude rules are sometimes fewer and less consequential than the mistakes that decidedly nonideal decision makers will make in the absence of rule-based guid-

${ }^{111}$ Alex Stein also challenges the Free Proof tradition, but on grounds quite different from those advanced here. Stein insightfully sees the rules of evidence as allocating the risks of error as between the parties, but offers little other than a brief nod to transparency and separation of powers on why such a goal need be served by rules as opposed to case-by-case allocation. STEIN, supra note 6, at 107-40; Alex Stein, The Refoundation of Evidence Law, 9 CAN. J.L. \& JURISPRUDENCE 279, 285-86 (1996). By contrast, the argument here rests primarily on the virtues of rules as rules in an epistemic context, independent of the substantive goals that such rules might serve. Erica Beecher-Monas argues that a structured (rule-based) reasoning process for evidentiary determinations serves due process goals, and that judges should serve as gatekeepers for the jury. Erica Beecher-Monas, Heuristics, Biases, and the Importance of Gatekeeping, 2003 MiCH. ST. L. REV. 987, 989-90. She does not, however, address directly the question of who should serve as the gatekeepers for the judges, although elsewhere she maintains, correctly in my view, that judges should use heuristics in making their own determinations about the admissibility of scientific evidence. Erica Beecher-Monas, The Heuristics of Intellectual Due Process: A Primer for Triers of Science, 75 N.Y.U. L. REV. 1563, 1589-90 (2000). 
ance, ${ }^{112}$ then just this argument, at one higher remove, may suggest that the mistakes embedded in a distinctly non-ideal set of rules may turn out to be less than the mistakes that would come from empowering some non-ideal group of rule makers to start anew, or from expecting some nonideal group of rule appliers to apply an array of newer rules with which they are much less familiar. Or, to put it somewhat more directly, at times it is genuinely optimizing to leave well enough alone.

Still, it may not be the case that the mistakes incorporated in the existing array of evidence rules-many of which are the function of hoary but mistaken psychological assumptions-are fewer in number and consequence than the mistakes that would come from creating a new and unfamiliar set of evidence rules, even after we have accepted the idea that the Free (or Free-er) Proof approach is flawed and that a rule-based understanding of evidence has much to commend it. And although I cannot even sketch here the beginnings of what such a new, but still rule-based, approach to evidence-for judges and juries alike-would look like, providing a few examples may still be in order.

The most obvious place to start is with the hearsay rule, because this is the rule, constitutional issues of confrontation in criminal cases aside, ${ }^{113}$ that is most under attack. As discussed above in Part III, it is the rule perhaps most widely ignored by trial judges sitting without a jury, it is the stock example in the academic literature advocating the relaxation or elimination of many of the rules of evidence, it is often the subject of calls for dramatic constriction or elimination, ${ }^{114}$ and it

${ }^{112}$ See ALEXANDER \& SHERWIN, supra note 72, at 53-95 (exploring the tension between the imperfection of rules and the hazard of an unbound decision maker); SCHAUER, PlaYing BY THE RUles, supra note 63, at 100 ("[A] system ... attains the benefits brought by rules only by relinquishing its aspirations for ideal decisionmaking."); Louis Kaplow, Rules Versus Standards: An Economic Analysis, 42 DuKE L.J. 557, 586-96 (1992) (exploring the implications of overinclusiveness and underinclusiveness in determining the favorability of rules versus standards); Russell B. Korobkin, Behavioral Analysis and Legal Form: Rules vs. Standards Revisited, 79 OR. L. REV. 23, 43 (2000) (expressing a preference for rules when citizens and adjudicators are not both "relatively perceptive ... and homogeneous"). But see Frederick Schauer, The Convergence of Rules and Standards, 2003 N.Z. L. REV. 303 (considering the possibility that rules and standards may converge over time, making the choice between them less consequential).

${ }^{113}$ See supra note 47.

114 See, e.g., Richard D. Friedman, Toward a Partial Economic, Game-Theoretic Analysis of Hearsay, 76 MinN. L. REv. 723, 724-25 (1992) (observing that criticisms of the hearsay rule "will not... surprise anybody familiar with the evidentiary debate"); Park, supra note 49, at 54 (arguing that the hearsay rule should be retained in criminal cases but substantially limited in civil litigation); Eleanor Swift, Abolishing the Hearsay Rule, 75 
has, by statute, been significantly diminished in the United Kingdom. ${ }^{115}$ Yet despite this onslaught, there remain sound reasons to believe that the hearsay rule would desirably continue in a rule-based approach to the law of evidence. Initially, all of the cognitive arguments set out in Part V above would apply plainly to hearsay, such that we can expect there to be approximately as much reason to doubt a judicial weighing of the value of hearsay evidence as a jury weighing. And once we have put the likely fallacy of comparative juror cognitive incompetence to rest, the principal reason for rejecting a hearsay rule is eliminated as well. ${ }^{116}$ In addition, and perhaps more importantly, the hearsay rule serves an important evidence-generating function, or, to put it differently, an important best evidence-in the nontechnical sense of that term-role. ${ }^{117}$ By excluding hearsay evidence (subject to all of the usual qualifications, caveats, exemptions, and exceptionsor at least many of them), the hearsay rule compels the parties to search for more rather than less direct accounts, and to locate and bring forward the most immediate and cross-examinable witnesses. ${ }^{118}$ Although an exclusion of hearsay will exclude some relevant evidence, such an exclusion will also compel the production of some better evidence, and it may well be that the aggregate value of the better evi-

CAL. L. REV. 495, 518-19 (1987) (advocating replacing the current hearsay rule in some circumstances with a requirement for "foundation witnesses" who testify as to the origin and reliability of the hearsay).

${ }^{115}$ Criminal Justice Act, 1988, c. $33 \S \S 26-28$ (Eng.); see also Evidence Act, 1995, pts. 3.1-3.2 (Austl.); Evidence Act, 1995, $§ \S 55-75$ (N.S.W., Austl.).

${ }^{116}$ There are some empirical studies of jury evaluation of hearsay, but none directly addressed to the comparative question of judge-juror competence. See, e.g., Margaret Bull Kovera et al., Jurors' Perceptions of Eyewitness and Hearsay Evidence, 76 MINN. L. REV. 703, 719 (1992) (observing that "juries rely more heavily on eyewitness testimony than hearsay testimony"); Peter Miene et al., Juror Decision Making and the Evaluation of Hearsay Evidence, 76 MINN. L. REV. 683, 699 (1992) (finding that in a mock juror study, introducing hearsay to a case based on circumstantial evidence raised the conviction rate by four percent, and that the conviction rate in mock cases based on eyewitness testimony actually decreased when hearsay was introduced); Regina A. Schuller, Expert Evidence and Hearsay: The Influence of "Secondhand" Information on Jurors' Decisions, 19 L. \& HUM. BEHAV. 345, 357 (1995) (indicating that jurors exposed to hearsay with limiting instructions reached similar verdicts to those exposed to the same information in admissible form).

${ }^{117}$ That many of the rules of evidence are better understood as attempts to generate the best available evidence is an insight that has been prominently pressed by Dale Nance. See, e.g., Dale A. Nance, Conditional Probative Value and the Reconstruction of the Federal Rules of Evidence, 94 MiCH. L. REV. 419 (1995); Dale A. Nance, Conditional Relevance Reinterpreted, 70 B.U. L. REV. 447, 448 (1990); Nance, supra note 16, at 270-94.

${ }^{118}$ On the view that evidence is something produced and created, and not just there, see Mark Cooney, Evidence as Partisanship, 28 LAW \& SOC'Y REV. 833, 834 (1994). 
dence marginally developed will be greater than the aggregate loss of the relevant evidence marginally excluded.

With respect to the connected issues of character and past acts, the analysis is different but the conclusions are much the same. Here the weight of modern social science research suggests that the concerns about overweighting are sound. ${ }^{119}$ And since much of the conventional academic and judicial wisdom is that evidence of past acts, prior behavior, and pertinent character is indeed highly probative, ${ }^{120}$ perhaps here, more than anywhere, do we need the exclusionary rules even more for the judges who have such a belief than for jurors, or, at the very least, no less. Moreover, the same evidence-generating considerations apply here as for hearsay, considerations that are agnostic as between jury and jury-free trials. If the adjudicative system has good moral and epistemic reasons for preferring evidence closely targeted to the particular act at issue, ${ }^{121}$ then the exclusion of evidence of past acts and general traits of character, even if relevant, will provide

${ }^{119}$ Some of the research is cited and discussed in Campbell v. Greer, 831 F.2d 700, 707 (7th Cir. 1987); see also Joel Schrag \& Suzanne Scotchmer, Crime and Prejudice: The Use of Character Evidence in Criminal Trials, 10 J.L. ECON. \& ORG. 319, 341 (1994) (arguing that allowing character evidence can make the jury too punitive toward habitual criminals). But see Susan Marlene Davies, Evidence of Character to Prove Conduct: A Reassessment of Relevancy, 27 CRIM. L. BULL. 504, 532 (1991) ("[T] he view that character evidence in general is not probative of conduct can no longer draw support from the psychological materials."). Much of the research is directed to exposing what in the literature is typically referred to as the "fundamental attribution error." See RICHARD NisBetT \& LEe Ross, Human InfEREnCE: STRATEgIES AND SHORTCOMINGS OF SOCiAL JUDGMENT (1980) (defining the fundamental attribution error as "the tendency to attribute overt behaviors to corresponding personal dispositions, thereby underestimating the causal role of environmental influences").

${ }^{120}$ See United States v. Daniels, 770 F.2d 1111, 1116 (D.C. Cir. 1985) (conceding that evidence of prior similar acts is not excluded because it is logically irrelevant); David P. Bryden \& Roger C. Park, "Other Crimes" Evidence in Sex Offense Cases, 78 MinN. L. REV. 529, 571 (1994) (recognizing the probative value of evidence of a defendant's history of sex crimes); H. Richard Uviller, Evidence of Character to Prove Conduct: Illusion, Illogic, and Injustice in the Courtroom, 130 U. PA. L. REV. 845, 848-49, 882-85 (1982) (arguing that evidence of prior similar acts can be highly probative under certain circumstances, and should be admitted); see also Boardman v. Dir. of Pub. Prosecutions, (1974) 3 All E.R. 887, 892-95 (H.L.) (substantially restricting the application of the "propensity rule," which excluded evidence of prior similar incidents).

${ }^{121}$ See United States v. McCourt, 925 F.2d 1229, 1235-36 (9th Cir. 1991) ("Our system of justice should not permit the trier of fact to infer that because someone was a bad guy once, he is likely to be a bad guy again.”); United States v. Mothershed, 859 F.2d 85, 89 (8th Cir. 1988) (announcing that "[w]e do not convict people of crimes simply because of their propensities; we do so because of what they have actually done"); United States v. Hodges, 770 F.2d 1475, 1479 (9th Cir. 1985) (concluding that a defendant "must be tried for what he did, not for who he is"). 
the incentives for the parties to provide evidence more focused on the particular acts and events at issue in the trial.

Similar conclusions might even apply to some aspects of the oftenscorned and increasingly narrow original documents rule. ${ }^{122}$ It is true that the rule in its traditional clothing imposes cumbersome requirements on the introduction of reliable secondary evidence, ${ }^{123}$ but there is little reason and no evidence to support the conclusion that judges and jurors differ with respect to the tendency to mis-evaluate secondary evidence that carries a whiff of suspicion. And there is no reason at all to believe that the presence or absence of a jury makes a difference with respect to the evidence-generating side. So insofar as it is desirable to have actual documents rather than, say, oral descriptions of them, the rule seems well-designed to create the correct incentives for the parties to preserve and come forward with the best evidence conceivably available, at least with respect to writings.

None of this is to say that there are not other evidentiary rules that we might well be rid of. But in many cases the arguments for discarding such rules apply to jury trials as well as judge-only trials, and thus even the rules we would and should jettison are rules that do not and should not depend on any comparative failures of juries vis-à-vis judges sitting alone. But the larger point is even more direct. Even if we reject the rule-based argument for keeping many of the rules we have just because we have them, a properly designed new set of evidence rules ${ }^{124}$ would have little tolerance for distinguishing between judge and jury, and would consequently wind up preserving even for nonjury proceedings more of the traditionally jury-focused rules than the typical judge or the typical Free Proof proponent has traditionally acknowledged.

${ }^{122}$ See supra notes 52-54 and accompanying text.

${ }^{123}$ See Michael H. Graham, Evidence and Trial Advocacy: The Original Writing (Best Evidence) Rule, 26 CRIM. L. Bull. 432, 435-38 (1990) (noting that the original documents rule prevents the admission of some witness testimony based on personal knowledge).

${ }^{124}$ Which would likely include new rules we do not now have. For example, Richard McAdams has suggested to me in conversation that cognitive problems of confirmatory bias-seizing on evidence supporting one's prior beliefs and ignoring evidence contradicting it-might suggest the necessity of substantially more rules about the order of presenting evidence than we now have. 


\section{CONCLUSION: SOME OPERATIONAL POSSIBILITIES}

Thus there are important issues to be explored-many of them empirical-before we quickly assume that judges can transcend those perceived cognitive and decisional failings of jurors that inspired the law of evidence in the first place. Moreover, if judges are, as often as jurors, subject to the kinds of decisional distortions that the exclusionary rules of evidence are designed to reduce, judicial awareness of the issue may not help very much. For even were judges to be fully aware of the problem of their own potential cognitive failings, and even were judges consequently to recognize the value of self-binding rules, it would likely remain the case that even the sophisticated judge recognizing the value of the self-binding rule would occasionally believe, sometimes correctly but sometimes erroneously, that this is the case in which the rule should not be applied, even taking into account the value of having the self-binding rule in the first place, and even taking into account the possibility of her own error in making this very assessment.

If we believe that this possibility of largely uncorrectable judicial error may exist, and if we therefore believe that on an excess number of occasions judges will mistakenly believe that the decision before them is not one in which the rule, all things considered, should apply, then there appears to be some need for a mechanism of external enforcement. But what form might such a mechanism of external enforcement take? Not only is there a harmless error rule as to constitutional issues in criminal cases, ${ }^{125}$ but there is also, and a fortiori, an obvious but less often discussed harmless error rule for civil cases and nonjury criminal cases in which erroneous evidentiary rulings do not present constitutional issues. ${ }^{126}$ That being the case, an important question is whether there remains any possible way in which trial

125 See Chapman v. California, 386 U.S. 18, 23-24 (1967).

126 See FED. R. EVID. 103(a) (requiring that "a substantial right of the party" be affected for a claim of error to be preserved); see also Doty v. Sewall, 908 F.2d 1053, 1057 (1st Cir. 1990) (noting that in civil cases, appellate courts need not review evidentiary decisions unless a "substantial right" of a party is affected). Indeed, the attitude is even more deferential than suggested in the text, because some appellate courts have gone beyond the harmless error principle to create a presumption that judges sitting without a jury have not relied on any erroneously received inadmissible evidence. See Gov't of Canal Zone v. Jimenez, 580 F.2d 897, 898 (5th Cir. 1978) ("Since appellant's case was tried before a Judge, we do not have to determine whether this evidence was admissible.”); United States v. Allstate Mortgage Corp., 507 F.2d 492, 494 (7th Cir. 1974) ("Absent a showing of substantial prejudice, the court, in a bench trial, is deemed to have considered only admissible and relevant material.”). 
judges sitting without a jury could actually be forced to take the rules of evidence seriously, assuming now that it would be good for them to do so. If evidentiary issues do not in general wind up in appellate courts-and that is why, as the "case" books make clear, evidence is not a subject well learned or well taught by the use of cases, ${ }^{127}$ even assuming the general wisdom of a focus on appellate cases as a form of law school instruction-then it appears as if the normal vehicle for the correction of trial error is disproportionately unavailable for evidentiary issues. Indeed, one way of describing the current state of affairs is in terms of trial judges ignoring the rules of evidence in nonjury cases precisely because they know they can get away with it. Because the rules of evidence-as opposed to the particularized techniques of epistemic evaluation-impose second-order constraints on first-order epistemic judgments of admissibility, we might (or at least some of us might ${ }^{128}$ ) think that these are just the kinds of constraints that require external enforcers. And if the most common mechanism of external enforcement-appellate review—is unavailable, is there any hope for changing the current state of affairs?

One possibility, of course, is to change the current attitude of appellate courts about reviewing evidentiary rulings in noncriminal, non-constitutionally-implicated cases. But this approach is, at best, a remote possibility, in part because of the textual entrenchment of the harmless evidentiary error rule in Rule 103(a) of the Federal Rules of Evidence and its state counterparts, ${ }^{129}$ and in part because we have no reason to believe that appellate courts are much interested in increasing their workload in general, or in increasing the number of correctoutcome cases that they will scrutinize closely. The statutory issue aside, however, one might imagine that a change in the incentives created by the existing harmless evidentiary error rule could be effectuated insofar as appellate courts, without much increasing their workload, were to adopt the common technique of low-probability high-penalty enforcement. ${ }^{130}$ If the occasional trial judge who ignored the rules of evidence were to be subject to judicial scolding (and

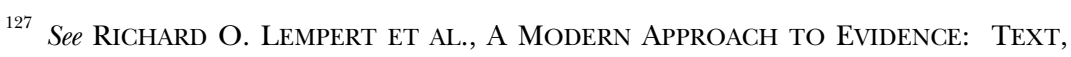
PROBLEMS, TRANSCRIPTS AND CASES, at ix (3d ed. 2000) ("This is not a casebook.").

${ }^{128}$ See Frederick Schauer, Judicial Supremacy and the Modest Constitution, 92 CAL. L. REV. 1045, 156-59 (2004).

${ }^{129}$ And also in 28 U.S.C. $\$ 2111$ (2006).

${ }^{130}$ The technique is especially useful for so-called white collar crimes, including tax crimes, and that is why law enforcement authorities are frequently so concerned to maximize the publicity attached to such cases. 
scoldings in appellate opinions are noticed, and likely have a substantial in terrorem effect on the future behavior of both the scolded judge and other judges as well), or if evidentiary mistakes were thought relevant to judicial promotion, for example, then it might well be that appellate courts now have at their disposal a moderately wide range of techniques for changing current behavior short of engaging in an extremely improbable course of reversing a large number of cases (most of which will have reached the right result) simply because of nonoutcome-changing evidentiary errors.

In terms of larger issues of institutional design, there exist in various decision-making domains mechanisms by which the fact-finding and decision-making functions are separated. Obviously the institution of the jury partakes of some of this, but it would be a mistake to move too quickly from recognizing some of the very real failings of juries to the conclusion that the merger of fact finding and law applying (or judgment rendering) is not itself without significant flaws. And this holds even more true with respect to the merger of the quite different tasks of determining admissibility and making a factual judgment on the basis of the admitted facts. Thus, and without getting into detail here, it may be possible to conceive of some number of institutional designs in which a significantly rule-based evidence-filtering process could maintain its rule-based features by separating that process from the goals of determining what happened as a matter of fact and then ultimately determining the outcome of some dispute. We see some of this in the process by which federal magistrates in searchand-seizure and confession cases make factual determinations to screen even from the trial judge those items of relevant, but unconstitutionally obtained, evidence that are best left out of the proceedings entirely. And the increasing use of discovery magistrates is an example of a process in which fact production is separated from fact finding. ${ }^{131}$ We can imagine various other designs in which separate proceedings and separate adjudicators in essence prepare the record which will then be the basis for decision by someone else. This is a common feature of various investigations outside of the formal legal process, in which corporate officials delegate an evidence-evaluating or fact-finding mission to others while retaining the power of final decision for themselves. Under such an approach the fact finders or evi-

${ }^{131}$ See, e.g., Crown Life Ins. Co. v. Craig, 995 F.2d 1376, 1379 (7th Cir. 1993). For some discussion of the idea, see Frank H. Easterbrook, Discovery as Abuse, 69 B.U. L. REV. 635, 639-40 (1989) (suggesting that such an arrangement is "unwise”). 
dence evaluators would be somewhat more inclined to see epistemic rule following as part of the very point of their enterprise, and would consequently be less inclined to discard those rules than if they saw those rules as obstacles in the way of reaching a final decision.

These possibilities are obviously remote in the short or intermediate term. Still, recognizing them might open up a wide range of possibilities for significant procedural reform to embody the importance of constraining judges as well as juries by exclusionary rules of evidence. But because such extreme forms of change in the institutional design of the trial are so unlikely in the foreseeable future, I will leave exploration of them for another occasion. At the moment, it is sufficient to conclude that it is hardly self-evident that the practices of so many trial judges in assuming that the rules of evidence are for other and lesser people is as beyond reproach and beyond remedy as is currently believed. More broadly, it is far from clear that the increasing academic and judicial momentum in favor of some form of Free Proof rests on solid empirical or conceptual foundations. Factual inquiry no less than normative legal prescription is usefully assisted by rules that are taken seriously, a point systematically neglected by the Free Proof tradition. That tradition, in the large as well as in some of its less ambitious manifestations, thus stands exposed of failing to explain why rules are important for law but not for facts, and of continuously clinging to a romantic image of the trial judge as a figure largely free of the cognitive failings we see and appreciate in lay jurors. Until the Free Proof tradition can meet the burden of explaining why these two significant omissions of justification do not substantially undercut the whole Free Proof idea, there will remain a significant place in the law of evidence for real rules that impose real constraints on real judges. In law this should come as little surprise. 